Article

\title{
Overexpression of a Mitogen-Activated Protein Kinase SIMAPK3 Positively Regulates Tomato Tolerance to Cadmium and Drought Stress
}

\author{
Tayeb Muhammad ${ }^{1,2}$, Jie Zhang ${ }^{1,2}$, Yalin Ma ${ }^{1,2}$, Yushun $\mathrm{Li}^{1,2}$, Fei Zhang ${ }^{1}$, Yan Zhang ${ }^{1,2, *}$ and \\ Yan Liang ${ }^{1,2, *}$ \\ 1 College of Horticulture, Northwest A\&F University, Yangling 712100, China; \\ tayebmuhammad@nwsuaf.edu.cn (T.M.); 15591858981@163.com (J.Z.); 15891785931@163.com (Y.M.); \\ liyushunaf@163.com (Y.L.); feizhang@nwsuaf.edu.cn (F.Z.) \\ 2 State Key Laboratory of Crop Stress Biology in Arid Regions, Northwest A\&F University, \\ Yangling 712100, China \\ * Correspondence: zhangyan2014@nwsuaf.edu.cn (Y.Z.); liangyan@nwsuaf.edu.cn (Y.L.); \\ Tel.: +86-29-87082179 (Y.Z.); +86-13060408001 (Y.L.); Fax: +86-029-87082149 (Y.L.)
}

Received: 10 December 2018; Accepted: 31 January 2019; Published: 3 February 2019

\begin{abstract}
Mitogen-activated protein kinases (MAPKs) activation is a common defense response of plants to a range of abiotic stressors. SIMPK3, a serine-threonine protein kinase, has been reported as an important member of protein kinase cascade that also functions on plant stress tolerance. In this study, we cloned SIMPK3 from tomato and studied its role in cadmium $\left(\mathrm{Cd}^{2+}\right)$ and drought tolerance. The results showed that transcripts of SIMAPK3 differentially accumulated in various plant tissues and were remarkably induced by different abiotic stressors and exogenous hormone treatments. Overexpression of SIMAPK3 increased tolerance to $\mathrm{Cd}^{2+}$ and drought as reflected by an increased germination rate and improved seedling growth. Furthermore, transgenic plants overexpressing SIMAPK3 showed an increased leaf chlorophyll content, root biomass accumulation and root activity under $\mathrm{Cd}^{2+}$ stress. Chlorophyll fluorescence analysis revealed that transgenic plants demonstrated an increased photosynthetic activity as well as contents of chlorophyll, proline, and sugar under drought stress. Notably, cadmium- and drought-induced oxidative stress was substantially attenuated in SIMAPK3 overexpressing plants as evidenced by lower malondialdehyde and hydrogen peroxide accumulation, and increased activity and transcript abundance of enzymatic antioxidants under stress conditions compared to that of wild-type. Our findings provide solid evidence that overexpression of SIMAPK3 gene in tomato positively regulates tolerance to $\mathrm{Cd}^{2+}$ and drought stress, which may have strengthen the molecular understanding of SIMAPK3 gene to improve abiotic stress tolerance.
\end{abstract}

Keywords: antioxidant enzymes; cadmium; drought; lipid peroxidation; reactive oxygen species; SIMAPK3; tomato

\section{Introduction}

Plants are sessile living organisms, often exposed to diverse biotic and abiotic stress conditions throughout their life cycles. Abiotic stress not only affects plant growth, yield, and quality but also limits the geographical distribution of many plants [1]. While most abiotic stressors occur naturally, human activities may change the abundance and severity of some stressors, such as heavy metals. Heavy metal toxicity is one of the serious environmental problems that affect both plants, animals and public health [2].

In plants, $\mathrm{Cd}^{2+}$ affects many physiological and metabolic processes by inducing oxidative stress [3]. High concentrations of $\mathrm{Cd}^{2+}$ disrupt membrane integrity and cause loss of function of the plasma membrane [4], chromosomal aberration, and leaf chlorosis [5,6]. Furthermore, toxic concentrations of 
$\mathrm{Cd}^{2+}$ can reduce seed germination, inhibit plant growth and cause wilting or even plant death [7-9]. Similarly, drought stress has profound detrimental effects on seed germination, plant growth, and crop productivity. Drought causes stomatal closure and reduces the activity and contents of the photosynthetic enzymes in carbon reduction cycle, including, ribulose-one, five-bisphosphate carboxylase/oxygenase [10]. On the other hand, plants have developed a variety of mechanisms to sense and cope with the unfavorable environmental conditions. Multiple signal transduction pathways function in concert to mediate plant adaptation to hostile environments [11]. One of the most important signaling modules that deliver perceived external stimuli to the nucleus is the mitogen-activated protein kinase (MAPK) cascade [12].

MAPK cascades regulate many essential biological processes, including growth, development and programmed cell death (PCD) in plants [13]. These are three-tiered phospho-relay cascade consisting of MAPKK kinases that activate via phosphorylation of their downstream MAPKKs, which in turn further activate MAPKs [14]. MAPKs in plants are classified into four different homologous groups (A, B, C, and $D$ ) on the basis of their sequence and conserved motifs [15], with members of families $A$ and $B$ being particularly involved in hormonal and environmental responses [16]. A total of 20 AtMAPKs and 16 SIMAPKs occur in Arabidopsis and tomato, respectively, and the transcript levels of nearly all SlMAPKs genes are significantly increased by stress [17].

The upstream kinases activate downstream kinases to activate various physiological functions, and it has been reported that reactive oxygen species (ROS), phosphatidic acid, and various hormones are also involved in the activation of MAPK cascade [18-20]. Previous reports have shown that MKK9 activates MPK3/MPK6 to regulate the ethylene biosynthesis and signaling, leaf senescence and phosphate acquisition [21-24]. In Arabidopsis, the AtMKK2 phosphorylates AtMPK4 and AtMPK6 (downstream kinases) after being stimulated by cold and salt stress [25], whereas mechanical wounding [26] and osmotic stress activate MAPK3 [27]. The MAPK cascades also receive various signals to induce resistance against different biotic stressors. In Nicotiana tabacum (tobacco) two MAPKs, salicylic acid (SA) induced protein kinase (NtSIPK) homologous to AtMPK6 and wounding induced protein kinase (NtWIPK) homologous to AtMPK3 in Arabidopsis, are activated in an N-gene-dependent manner to mount local and systemic antiviral defense responses [28]. Ethylene, salicylic acid, and MAPK-related defense signaling pathways enhance resistance to bacterial wilt, and the induction of plant aminocyclopropane carboxylic acid oxidase (ACO) gene family occurs through MPK1-, 2, and 3 pathways following diethyl ether (ether) treatment [29,30].

Tomato LeMPK1, LeMPK2, and LeMPK3 are activated in response to fungal toxin fusicoccin [31], and have roles in hypersensitive response (HR) and resistance [32]. Similarly LeMPK1, LeMPK2, and LeMPK3 are induced by ultraviolet-B (UV-B) radiations and the dual specificity of LeMPK3 characterizes a convergence point for numerous signaling pathways that induce defense responses [33]. In addition, previous results reveal that SPMPK3 influences stomatal activity and hydrogen peroxide $\left(\mathrm{H}_{2} \mathrm{O}_{2}\right)$ accumulation through the abscisic acid (ABA) $-\mathrm{H}_{2} \mathrm{O}_{2}$ pathway to enhance drought tolerance in tomato and also functions in Arabidopsis seed germination and seedling development during osmotic stress [34,35].

Cultivated tomato is susceptible to a wide range of stressors and researchers have long been studying potential genes for resistance in plants. However, the gene expression, signal transduction, and cellular responses to stress remain unclear, under $\mathrm{Cd}^{2+}$ stress. Thus, considering the importance of MAPK3 in stress tolerance, we cloned SIMAPK3 gene to investigate its functions against cadmium and drought stresses. Our results showed that overexpression of SIMAPK3 enhanced tolerance to $\mathrm{Cd}^{2+}$ and drought stress by improving multiple morphological and physiological characters.

\section{Results}

\subsection{Characterization of SIMAPK3 Gene}

We isolated SIMPK3 from tomato using specific primers. The SIMPK3 cDNA contains an 1122-bp open reading frame (ORF) with a total length of 1657-bp long. The untranslated regions are 129-bp 
and 406-bp at 5' and $3^{\prime}$ ends, respectively (https:/ / www.ncbi.nlm.nih.gov/nuccore/NM001247431). Tomato genome database showed that the SIMAPK3 gene is located on chromosome 6, encoding a protein of 373 amino acids having approximately $42.66 \mathrm{kDa}$ molecular weight and an iso electric point 5.25. Tomato MAPKs family contains 16 genes [17]. On the basis of phylogenetic analysis, they are divided into four groups and MAPK3 belongs to the group A having two other members of the family (Figure S1A). Amino acid analysis showed that MAPKs family contains Serine/Threonine protein kinases catalytic domain. Furthermore, the catalytic domain of SIMAPK3 consists of total 288 amino acids (Figure S1B).

\subsection{Expression Analysis of SIMAPK3}

Tissue-specific expression analysis revealed that transcript levels of the SIMAPK3 were higher in stems, roots, and flowers as compared to other tissues of Solanum lycopersicum (Figure 1A). To understand the role of SIMAPK3, the expression pattern of SIMAPK3 was studied in response to various abiotic stressors and hormonal treatments. Real-time reverse transcription-PCR (RT-PCR) analysis revealed that the transcript levels of SIMAPK3 increased in response to cadmium, dehydration, salt, heat, ABA, methyl jasmonate (MeJA) and SA treatments. SIMAPK3 was gradually induced by cadmium, drought and salt treatments, reaching the maximum levels following 6, 3 and $3 \mathrm{~h}$ exposure, respectively. However, in case of the heat stress, the expression levels of SIMAPK3 reached the highest peak after $24 \mathrm{~h}$ exposure (Figure 1B). Hormonal application rapidly up-regulated expression levels of SIMAPK3, which peaked after $1 \mathrm{~h}$ treatment and then declined (Figure S2).
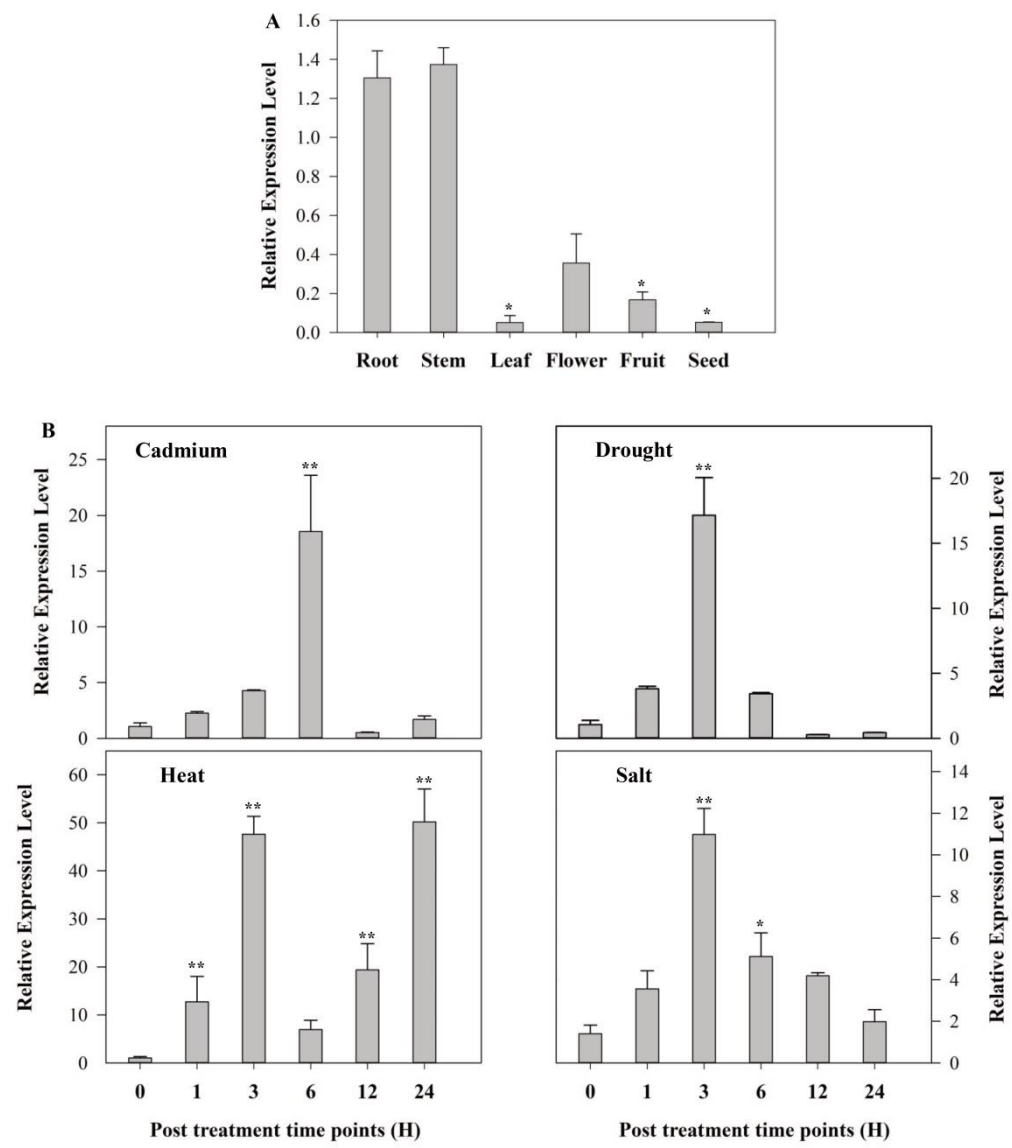

Figure 1. Transcript levels of SIMAPK3 in tomato as influenced by different tissues types and abiotic stressors. (A) SIMAPK3 expression in different plant tissues, and (B) time course of SIMAPK3 transcript under abiotic stresses induced by cadmium $\left(150 \mu \mathrm{M} \mathrm{CdCl}_{2} 2.5 \mathrm{H}_{2} \mathrm{O}\right)$, drought (dehydration), heat $\left(40{ }^{\circ} \mathrm{C}\right)$ and salt $(200 \mathrm{mM} \mathrm{NaCl})$. Data represent mean $\pm \mathrm{SE}$ of three biological replicates. ${ }^{* *},{ }^{*}$ significant level differed at $p<0.01$ and $p<0.05$, respectively. 


\subsection{Identification of Transgenic Plants}

To generate transgenic plants, the full coding sequence of SIMAPK3 was cloned in to binary vector under the control of cauliflower mosaic virus (CaMV) $35 \mathrm{~S}$ promoter and the resultant vector was transfer through Agrobacterium tumefaciens mediated transformation. The transgenic lines were screened for kanamycin resistance and then confirmed by genomic PCR (Figure S3). The relative expression of five homozygous lines were normalized to the wild-type expression level (wild-type $=1.0$ ) and qRT-PCR analysis revealed that transgenic lines exhibited high expression levels than wild-type (Figure 2). The three independent lines, L-4, L-6, L-7, with relatively high expression levels were selected for further experiments.

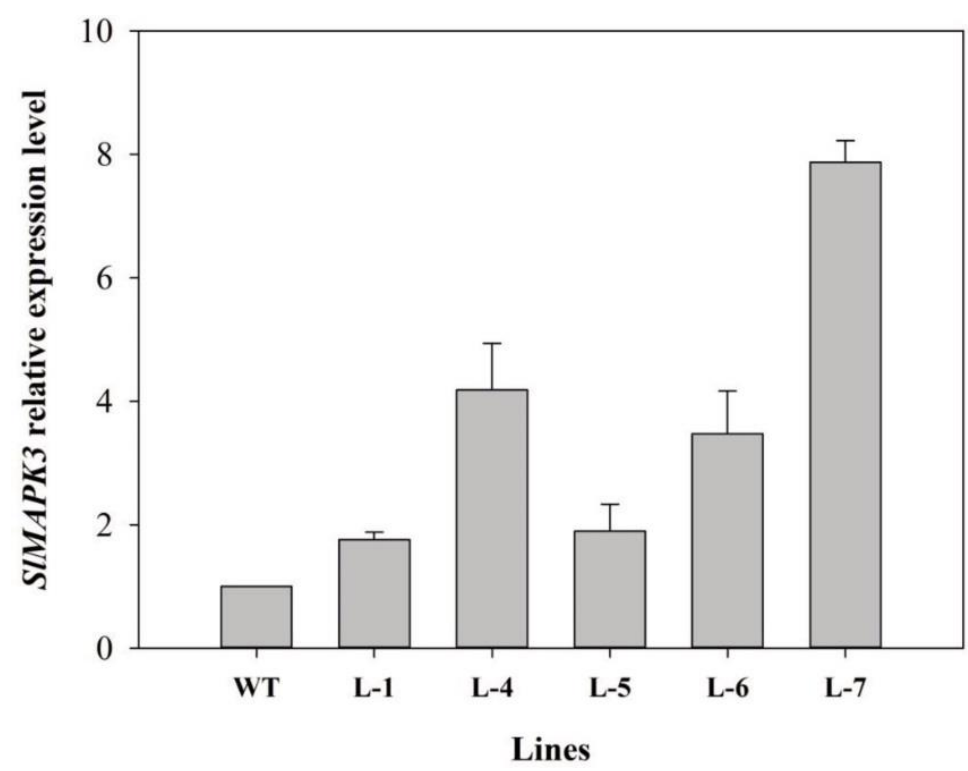

Figure 2. Expression levels of SIMAPK3 in wild-type and transgenic lines. Expression data were normalized with SIMAPK3 expression in WT as 1. Error bars show the standard error between three replicates.

\subsection{Growth Analysis of Seedlings Under Cadmium Stress}

To study the possible role of SIMAPK3 gene in cadmium tolerance, both wild-type (WT) and transgenic lines were germinated on $\frac{1}{2}$ strength Murashige and Skoog (MS) medium supplemented with 0 and $100 \mu \mathrm{M} \mathrm{Cd}^{2+}$. No substantial difference was observed between transgenic and WT lines at control condition. However, SIMAPK3-overexpressing lines showed significantly higher germination rate than WT when grown on the $\mathrm{Cd}^{2+}$ contaminated medium than WT (Figure 3B). We also investigated the growth of seedling under the same conditions by measuring the newly developed stem and the root of the seedlings. While no significant change was found between WT and three transgenic lines under the unstressed condition, the growth of hypocotyl and epicotyl increased by $57.6 \%$ and $49.81 \%$, respectively in transgenic plants as compared to that in WT plants under $\mathrm{Cd}^{2+}$ stress (Figure 3C,D). These findings indicate that SIMAPK3 overexpression enhanced tomato tolerance to cadmium stress during seed germination. 

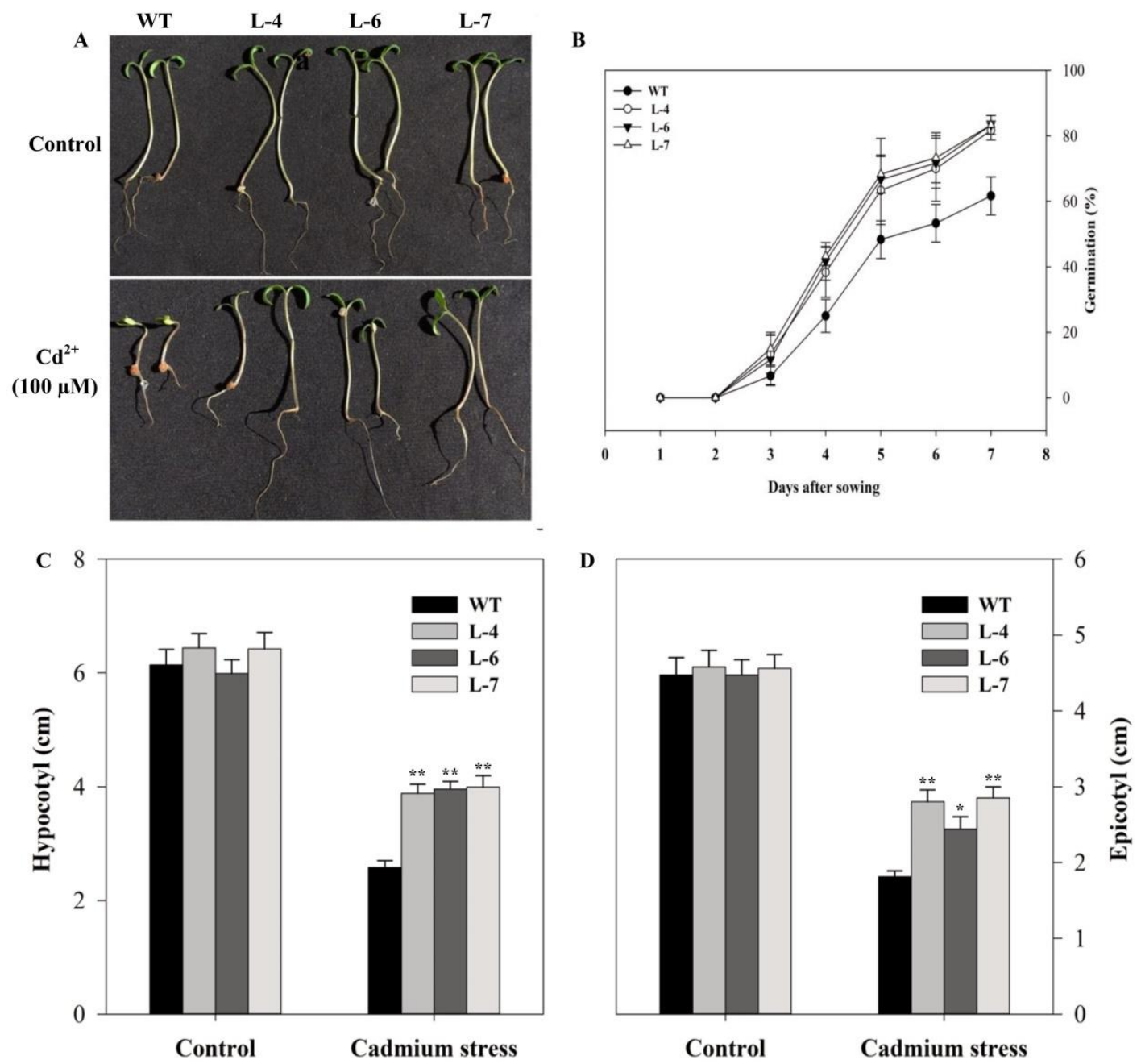

Figure 3. Seed germination and seedling growth of wild-type and SIMAPK3 overexpressed plants under cadmium stress. (A) Seedling phenotypes in the medium supplemented with 0 and $100 \mu \mathrm{M}$ cadmium. (B) Seed germination percentage under cadmium stress. (C) Hypocotyl length and (D) epicotyl length in control and cadmium stress conditions. Data represent mean $\pm \mathrm{SE}$ of three biological replicates. For $\mathrm{C}$ and $\mathrm{D},{ }^{* *},{ }^{*}$ significant level differed at $p<0.01$ and $p<0.05$, respectively.

\subsection{SlMPK3 Overexpression Improves Plant Tolerance to $\mathrm{Cd}^{2+}$ Stress}

To further evaluate the possible role of SIMAPK3 in plant tolerance to cadmium stress, tomato plants at five-leaf-stage were subjected to $\mathrm{Cd}^{2+}$ stress. After 7- and 14-days stress treatments, chlorosis was observed in leaves of both transgenic and WT seedlings, but the symptoms were more severe in WT as compared to that in overexpressed lines. On the other hand, no chlorosis in leaves was found in all lines under the control condition (Figure 4B). In line with the visual observation, spectrophotometric analysis also showed that $\mathrm{Cd}^{2+}$ stress significantly reduced chlorophyll content in leaves. Compared with the transgenic lines, the chlorophyll content decreased by $38.01 \%$ and $17.9 \%$ in control plants following 7- and 14-days $\mathrm{Cd}^{2+}$ treatments, respectively (Figure 4C). Under control condition, malondialdehyde (MDA) and $\mathrm{H}_{2} \mathrm{O}_{2}$ contents remained similar in all plants. However, $\mathrm{Cd}^{2+}$ treatment resulted in a remarkable increase in $\mathrm{MDA}$ and $\mathrm{H}_{2} \mathrm{O}_{2}$, but the levels were significantly low in the overexpressed lines compared to that in the WT (Figure 4D,E). The MDA content of the WT plants increased 3.59 and 8.38 fold at 7- and 14-days after $\mathrm{Cd}^{2+}$ treatment, respectively, while in transgenic lines MDA content was significantly low compared to WT (Figure 4D). $\mathrm{H}_{2} \mathrm{O}_{2}$ accumulation also increased with the progression of $\mathrm{Cd}^{2+}$ stress, however, the accumulation of $\mathrm{H}_{2} \mathrm{O}_{2}$ was maximum in WT as compared to that in transgenic lines (Figure 4E). 

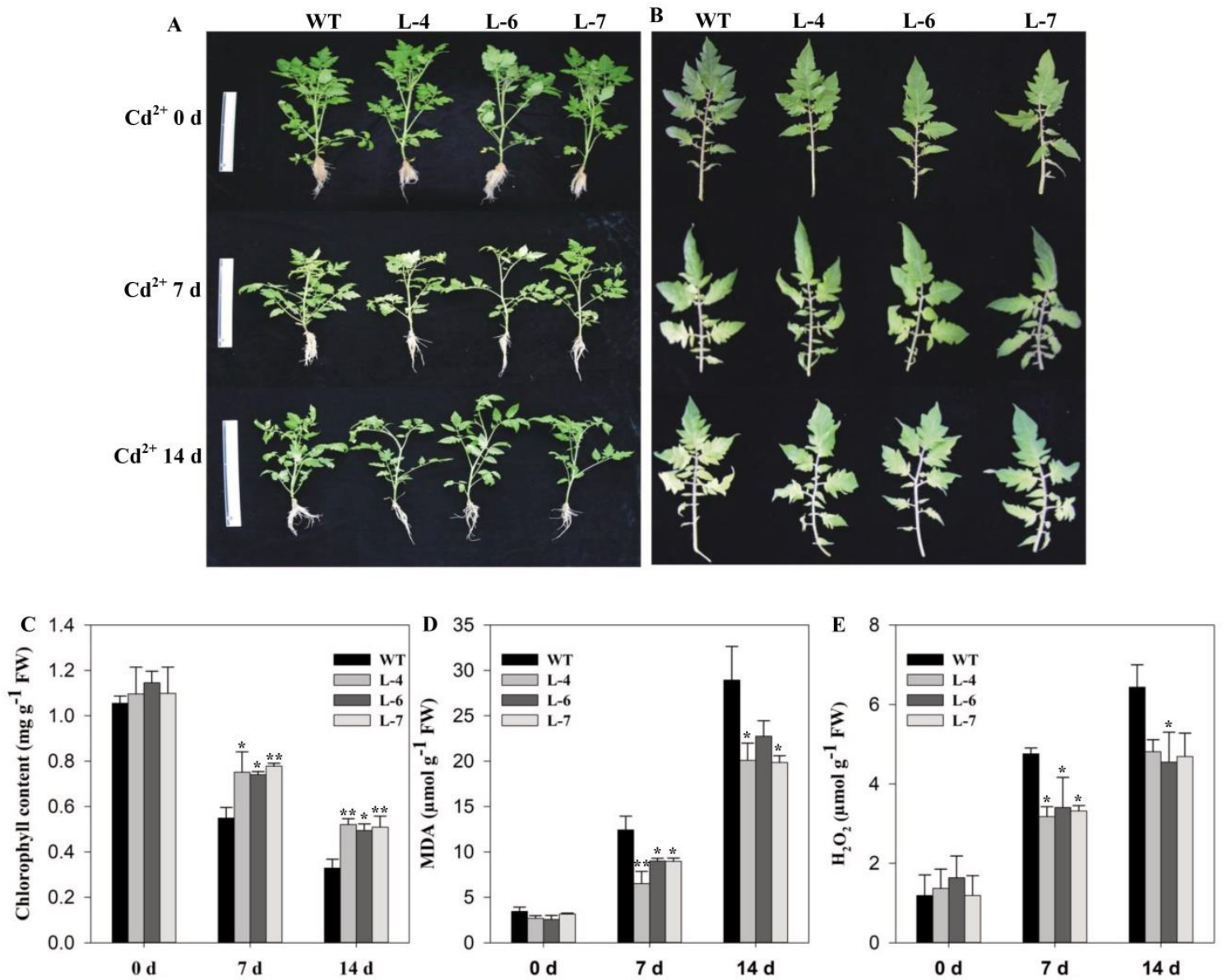

Figure 4. Overexpression of SIMAPK3 enhanced cadmium tolerance in tomato. (A) Plant phenotypes. (B) Images of the second leaves of WT and SIMAPK3 overexpressed lines (C) chlorophyll content, (D) malondialdehyde (MDA) content, and (E) $\mathrm{H}_{2} \mathrm{O}_{2}$ accumulation. Seedlings of WT and transgenic lines at five leaf-stage were treated with 0 (0 days) and $100 \mu \mathrm{M}$ (7- and 14-days) cadmium. For C-E, data represent mean $\pm \mathrm{SE}$ of three biological replicates. ${ }^{* *},{ }^{*}$ significant level differed at $p<0.01$ and $p<0.05$, respectively.

$\mathrm{Cd}^{2+}$ toxicity relates well with the inhibition of root growth, therefore, we studied the root morphology of WT and transgenic lines in control and $\mathrm{Cd}^{2+}$ stress conditions. It was observed that there was no change in root morphology in control condition, however, $\mathrm{Cd}^{2+}$ stress for 7 - and 14-days inhibited root growth in tomato genotypes but the maximum inhibition was found in WT as compared to transgenic lines (Figure 5A). From the measurements of the roots for different characteristics, we found that $\mathrm{Cd}^{2+}$ stress severely affected WT plants, as evidenced by the root weight and total length. Root fresh weight and dry weight were significantly higher in overexpressed plants than WT subjected to stress conditions (Figure 5B,C). Total root length was also significantly reduced in WT plants as compared to transgenic lines following $\mathrm{Cd}^{2+}$ stress (Figure 5D). Analysis of root activity showed a significant reduction after $\mathrm{Cd}^{2+}$ stress. At 14 -days post $\mathrm{Cd}^{2+}$ stress, the root activity of the WT plants was 2.18 fold lower than the average root activity of transgenic lines (Figure 5E). 

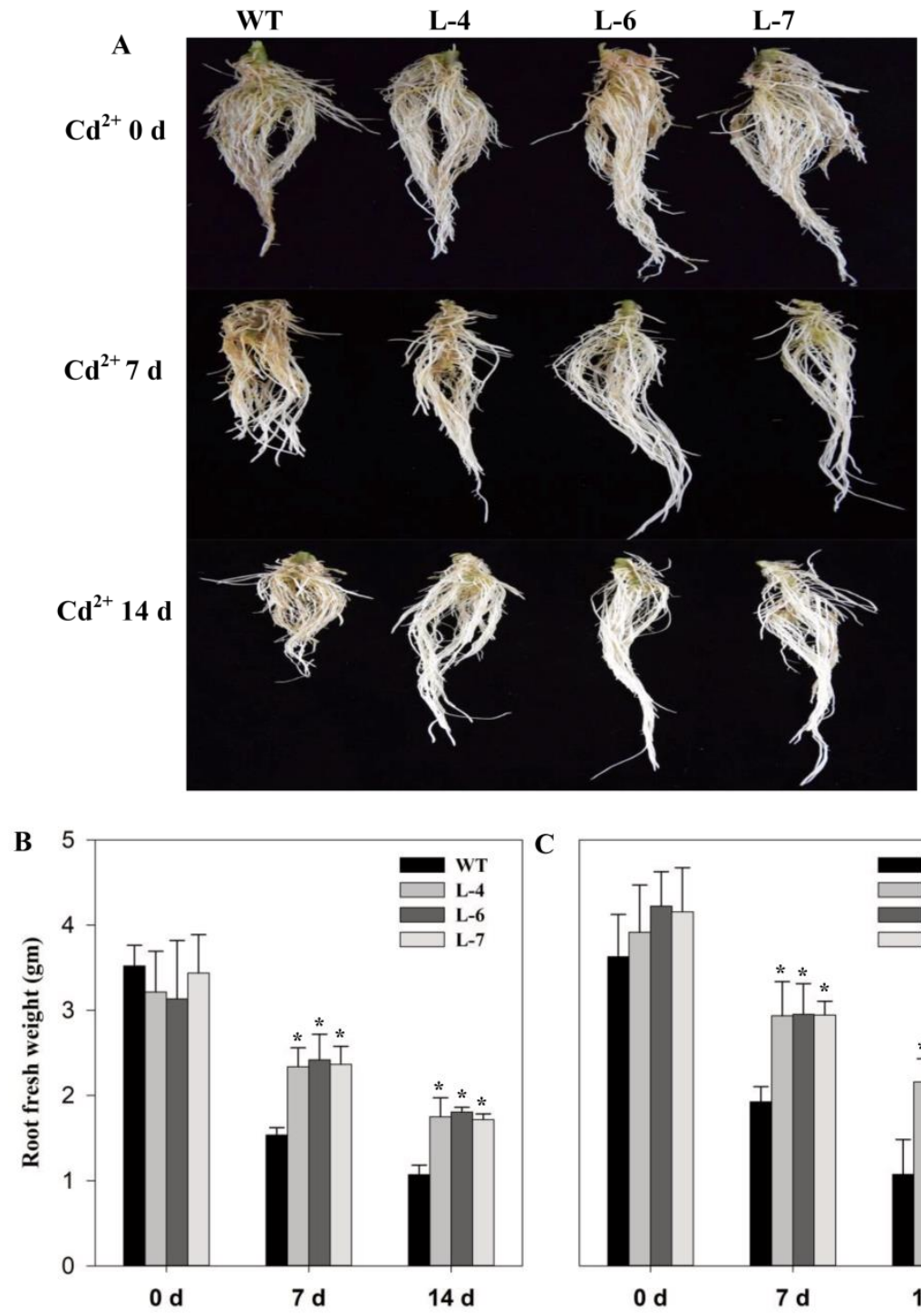

C
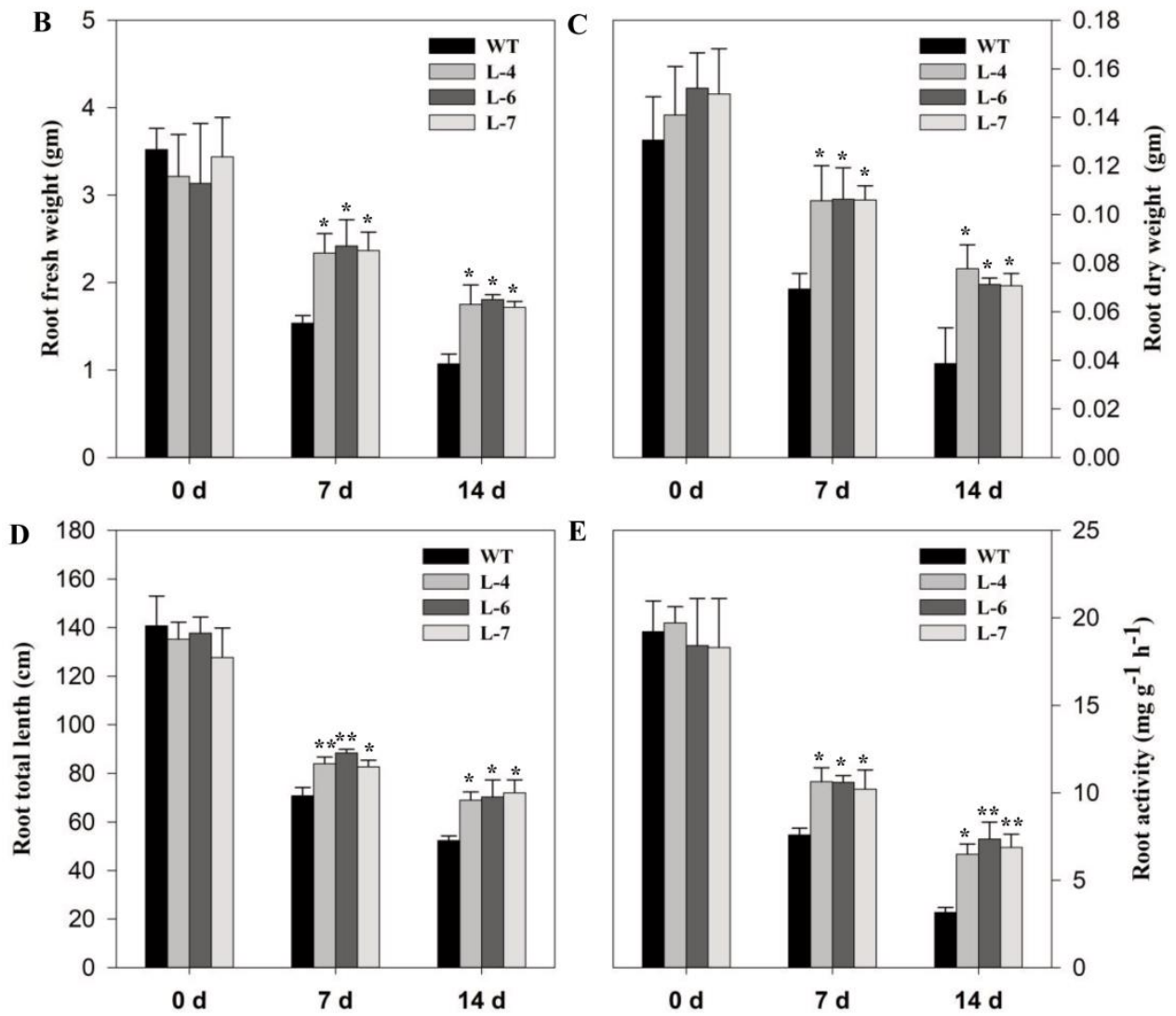

Figure 5. Overexpression of SIMAPK3 improved root morphology under cadmium stress in tomato. (A) Roots phenotype, (B) root fresh weight, (C) root dry weight, (D) root total length, and (E) root activity. Seedlings of WT and transgenic lines at five leaf-stage were treated with 0 ( 0 days) and $100 \mu \mathrm{M}(7-$ and 14-days) cadmium. For B-E, data represent mean \pm SE of three biological replicates. ${ }^{* *}$, * significant level differed at $p<0.01$ and $p<0.05$, respectively. 


\subsection{SlMPK3 Overexpression Enhances Enzymatic Antioxidant Potential under $\mathrm{Cd}^{2+}$ Stress}

Since stress conditions promote ROS accumulation, plants activate the antioxidant system to scavenge overproduced ROS and minimize ROS-induced damage. Therefore, antioxidant enzymes activities and the transcript levels of relevant genes were measured in both WT and transgenic lines after exposure of plants to $\mathrm{Cd}^{2+}$ stress for 7 - and 14-days. Under normal condition, there were no observable differences between wild-type and SIMPK3-overexpressed lines regarding antioxidant enzymes activity and proline content (Figure 6A-D).
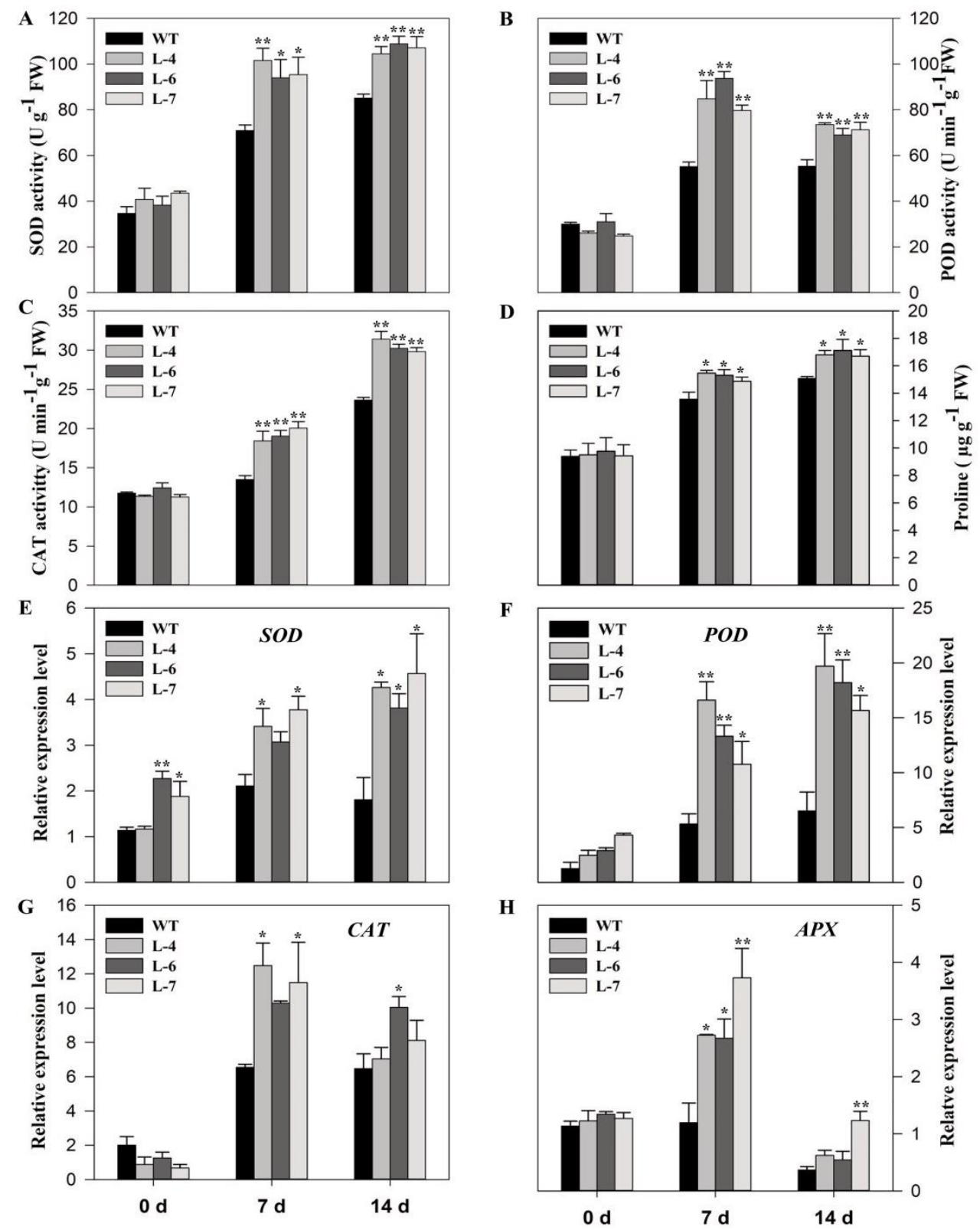

Figure 6. Antioxidant enzymes activities and transcript level of related genes in WT and transgenic lines under cadmium stress. (A-C) Activities of SOD, POD and CAT respectively. (D) Proline content and expression analysis of (E) SISOD, (F) SIPOD, (G) SICAT, and (H) SlAPX. Seedlings of transgenic lines and WT at five leaf stage were treated with 0 (0 days) and $100 \mu \mathrm{M}$ (7- and 14-days) cadmium. Data represent mean \pm SE of three biological replicates. ${ }^{* *},{ }^{*}$ significant level differed at $p<0.01$ and $p<0.05$, respectively. 
However, $\mathrm{Cd}^{2+}$ treatment significantly increased the superoxide dismutase (SOD) and catalase (CAT) activities at both at 7 - and 14-day post treatments (Figure 6A,C), while, peroxidase (POD) activity initially increased at 7-days and then decreased at 14-days post treatment in all tomato genotypes (Figure 6B). $\mathrm{Cd}^{2+}$ treatment also increased the levels of proline in both transgenic and WT plants, but the elevation was significantly higher in the overexpressed lines after 7- and 14-days of $\mathrm{Cd}^{2+}$ stress (Figure 6D). Overall, the antioxidant activity was significantly higher in transgenic lines than that in WT.

To further explore this mechanism, the transcript levels of antioxidant-related genes were studied in control and $\mathrm{Cd}^{2+}$-stressed plants. The expression of SISOD and SIPOD increased at 7- and 14-days after $\mathrm{Cd}^{2+}$ stress compared to the control that were not treated with $\mathrm{Cd}^{2+}$; however, the expression of SISOD and SIPOD remained higher in the three overexpressed tomato lines than in the WT (Figure 6E,F). The expression of SICAT and SIAPX, in the over-expressing lines initially increased at 7-days and then declined at 14-days (Figure 6G,H).

\subsection{Assessment of Drought Stress Tolerance in SIMAPK3-Overexpressed and Wild-Type Plants}

To evaluate the drought tolerance capability as influenced by SIMAPK3 overexpression, first, we tested the seed germination rate in WT and transgenic lines following treatment with mannitol (200 mM) supplemented medium. There were no observable differences in seedling length and germination rate between the transgenic and WT seedlings in a medium without mannitol (Figure 7A,B). However, in the presence of mannitol, the germination rate of WT plants decreased by approximately $61.35 \%$ compared with the transgenic lines (Figure 7B). There were no significant differences in leaf relative water content (RWC) and relative electrolyte leakage (REL) between overexpressed and wild-type plants under well-watered condition. After exposure of plants to drought stress for 15 days, water content and electrolyte leakage increased and decreased by $33.23 \%$ and $46.70 \%$, respectively in transgenic lines compared with that of WT plants, indicating that drought stress-caused membrane damage was severe in WT plants (Figure 7C,D). For further confirmation, water loss assay was performed with detached leaves. It was observed that the rate of water loss was faster and higher (by $14.14 \%$ ) in WT than that of SIMAPK3-overexpressing transgenic plants (Figure 7E).

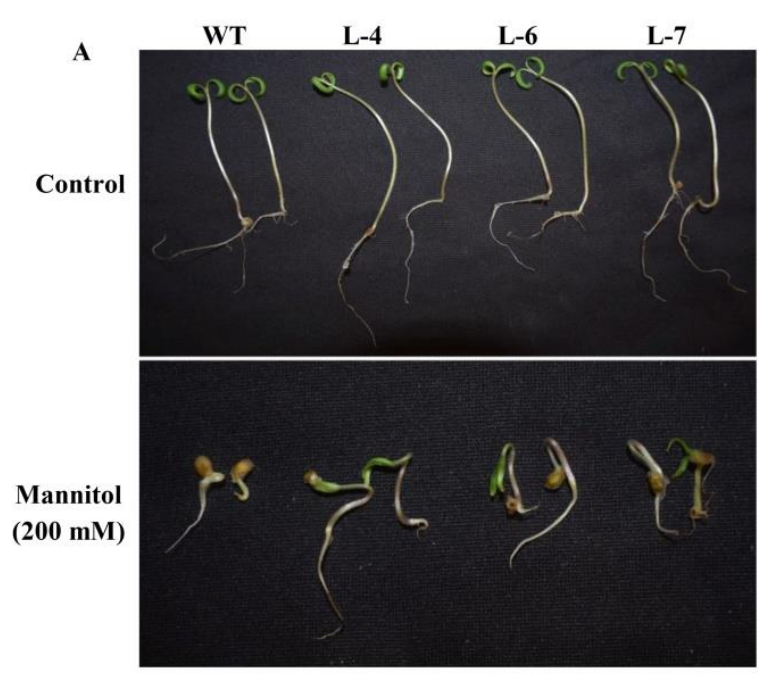

Figure 7. Cont. 


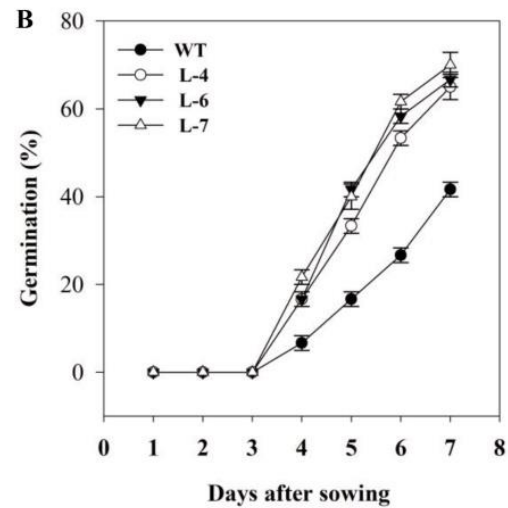

C

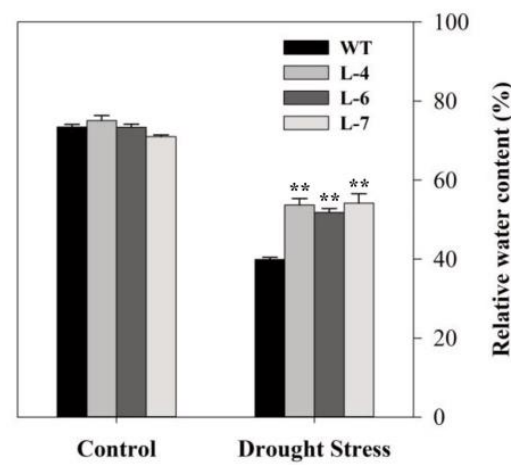

$\mathbf{E}$

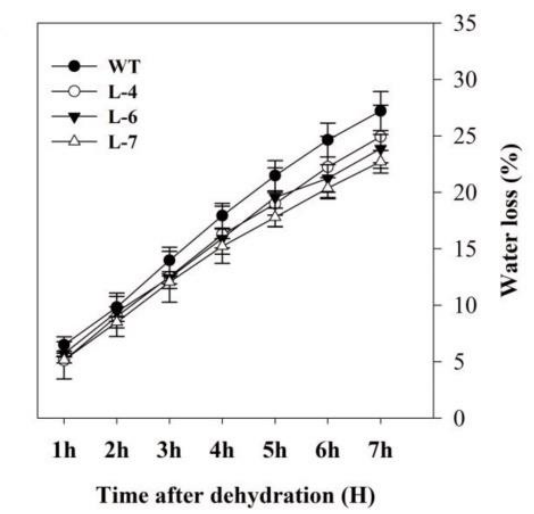

Figure 7. SIMAPK3 overexpression enhanced drought tolerance in tomato. (A) Seedling growth in 0 and $200 \mathrm{mM}$ mannitol stress, (B) seed germination percentage under $200 \mathrm{mM}$ mannitol stress, (C) relative water content, (D) relative electrolyte leakage, and (E) water loss in detached leaves. For B-E, data represent mean $\pm \mathrm{SE}$ of three biological replicates. For $\mathrm{C}$ and $\mathrm{D},{ }^{* *}$ significant level differed at $p<0.01$.

\subsection{Overexpression of SIMAPK3 Minimizes $\mathrm{H}_{2} \mathrm{O}_{2}$ Accumulation and Improves Photosynthetic Activity}

The transgenic and WT lines were exposed to dehydration stress for 15 days, and it was found that wilting of leaves was faster and more severe in WT plants than that of overexpressed plants (Figure 8A). Diaminobenzidine (DAB) staining showed no obvious difference between different lines under normal conditions. However, drought stress increased $\mathrm{H}_{2} \mathrm{O}_{2}$ accumulation, more profoundly in WT, as evidenced by the relatively intense dark brown color deposits compared to the normal condition (Figure 8B). Next, MDA content was measured as an indicator of lipid peroxidation. There were no apparent differences in the levels of this compound under normal conditions. However, drought stress significantly altered the levels of malondialdehyde in overexpressed and wild-type plants. The MDA content in three transgenic lines was approximately $41.40 \%$ lower than that of WT after drought stress (Figure 8C). Soluble sugar content showed no statistical variations between control and transgenic plants (except L-7) under normal condition. After drought treatment, soluble sugar content increased in all lines, however, SIMAPK3 overexpressing plants accumulated $37.93 \%$ higher soluble sugar than WT (Figure 8D). 

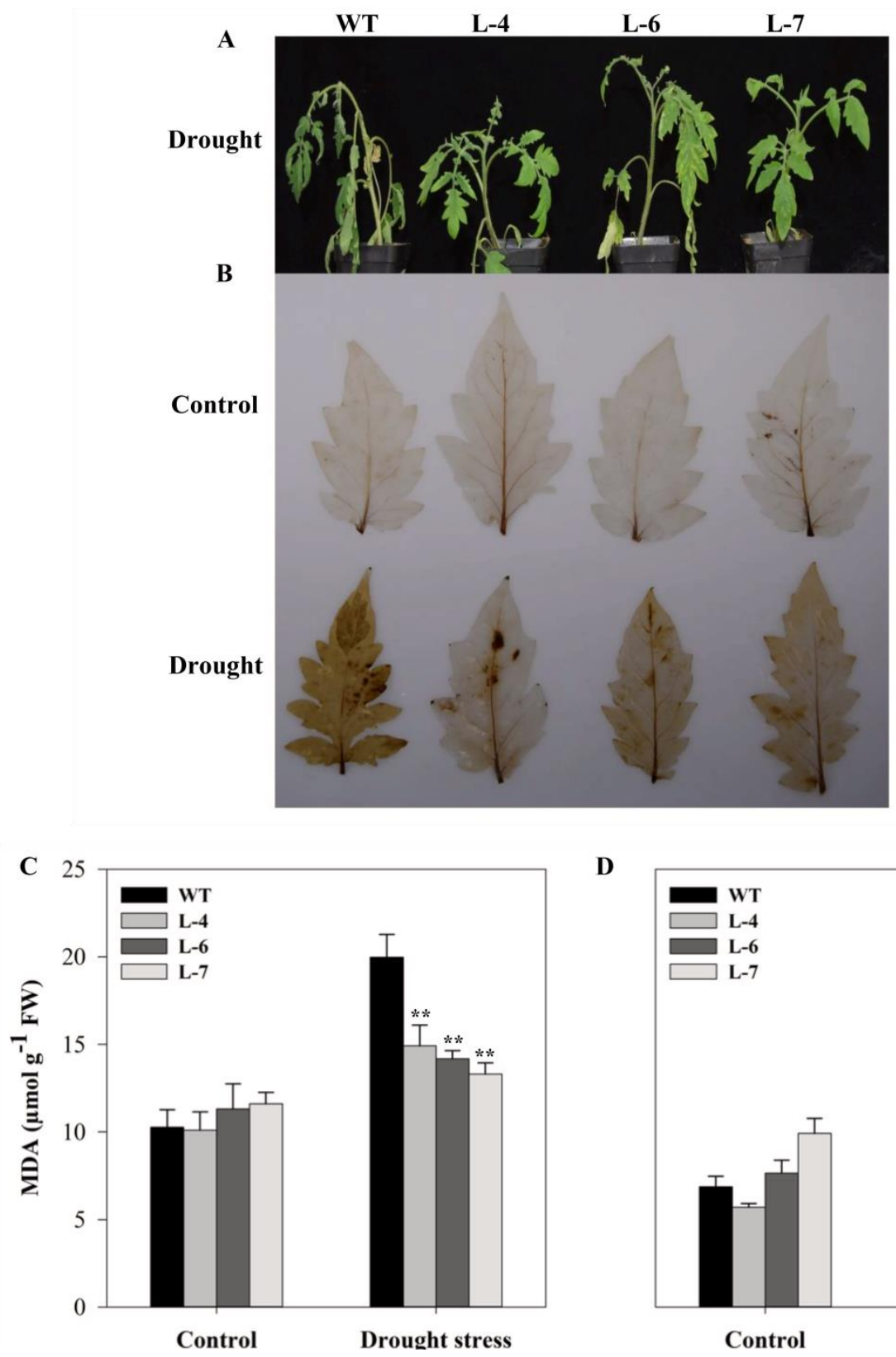

D

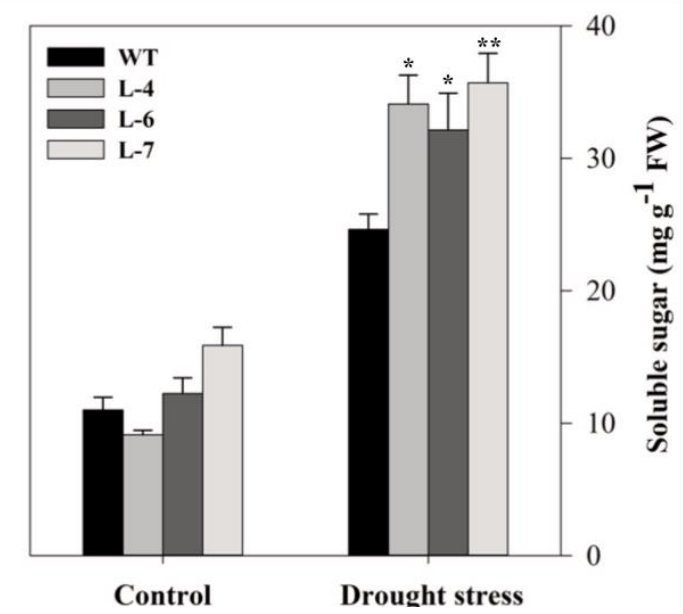

Figure 8. Overexpression of SIMAPK3 alleviated drought-induced oxidative stress in tomato. (A) Seedling phenotypes, (B) DAB staining for visualization of $\mathrm{H}_{2} \mathrm{O}_{2}$ accumulation, (C) MDA content, and (D) soluble sugar content. Six-week old seedlings of WT and transgenic lines were subjected to drought stress by withholding water supply for 15 successive days and well-watered plants (watered every alternate day) served as a control. For $\mathbf{C}$ and $\mathbf{D}$ data represent mean $\pm \mathrm{SE}$ of three biological replicates. ${ }^{* *},{ }^{*}$ significant level differed at $p<0.01$ and $p<0.05$, respectively.

Meanwhile, drought stress decreased chlorophyll content by $25.70 \%$ in WT plants as compared to overexpressing plants, while, no difference was found between them under irrigated condition (Figure 9A). We also analyzed some chlorophyll fluorescence parameters in two-month-old plants that were subjected to 20-days drought condition. The differences were not significant between WT and transgenic plants in terms of chlorophyll fluorescence parameters at well-watered conditions except for qP in L-6 and L-7 (Figure 9B-F). However, drought stress decreased quantum efficiency of PSII photochemistry (øPSII), the maximum photochemical efficiency of PSII ( Fv/Fm), the efficiency of energy capture by open PSII reaction centers $\left(F v^{\prime} / F m^{\prime}\right)$ and the efficiency of photochemical quenching 
$(\mathrm{qP})$ in both WT and overexpressing lines, but WT plants showed a greater decrease compared to that of overexpressing lines (Figure 9B-D and F). In case of non-photochemical quenching (NPQ), the efficiency increased after stress compared to the normal condition, being higher in the L-4 and L-7 than in the WT (Figure 9E).

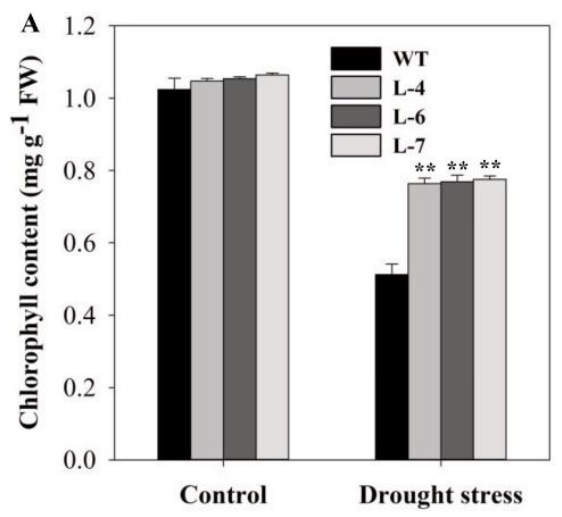

B
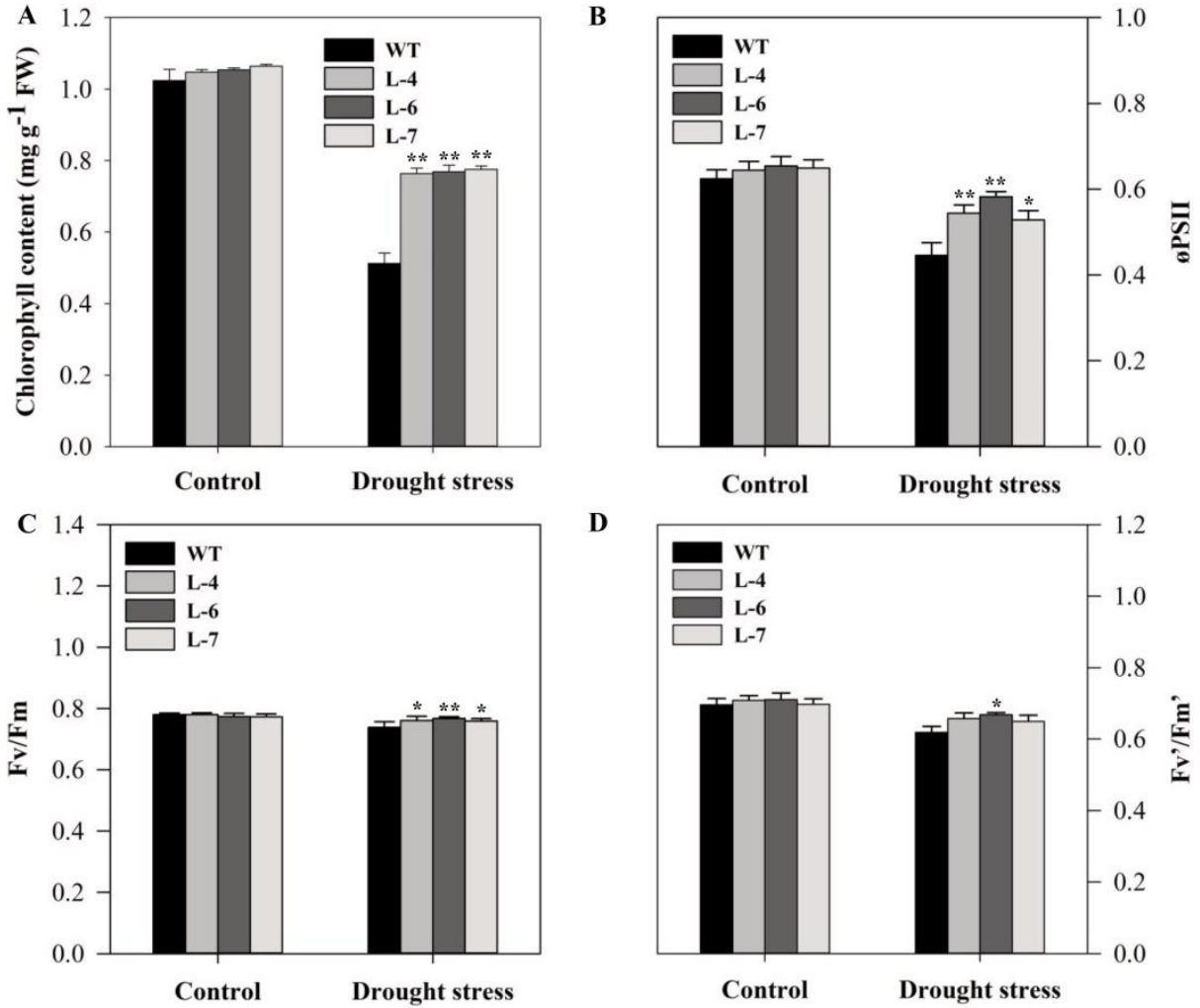

D
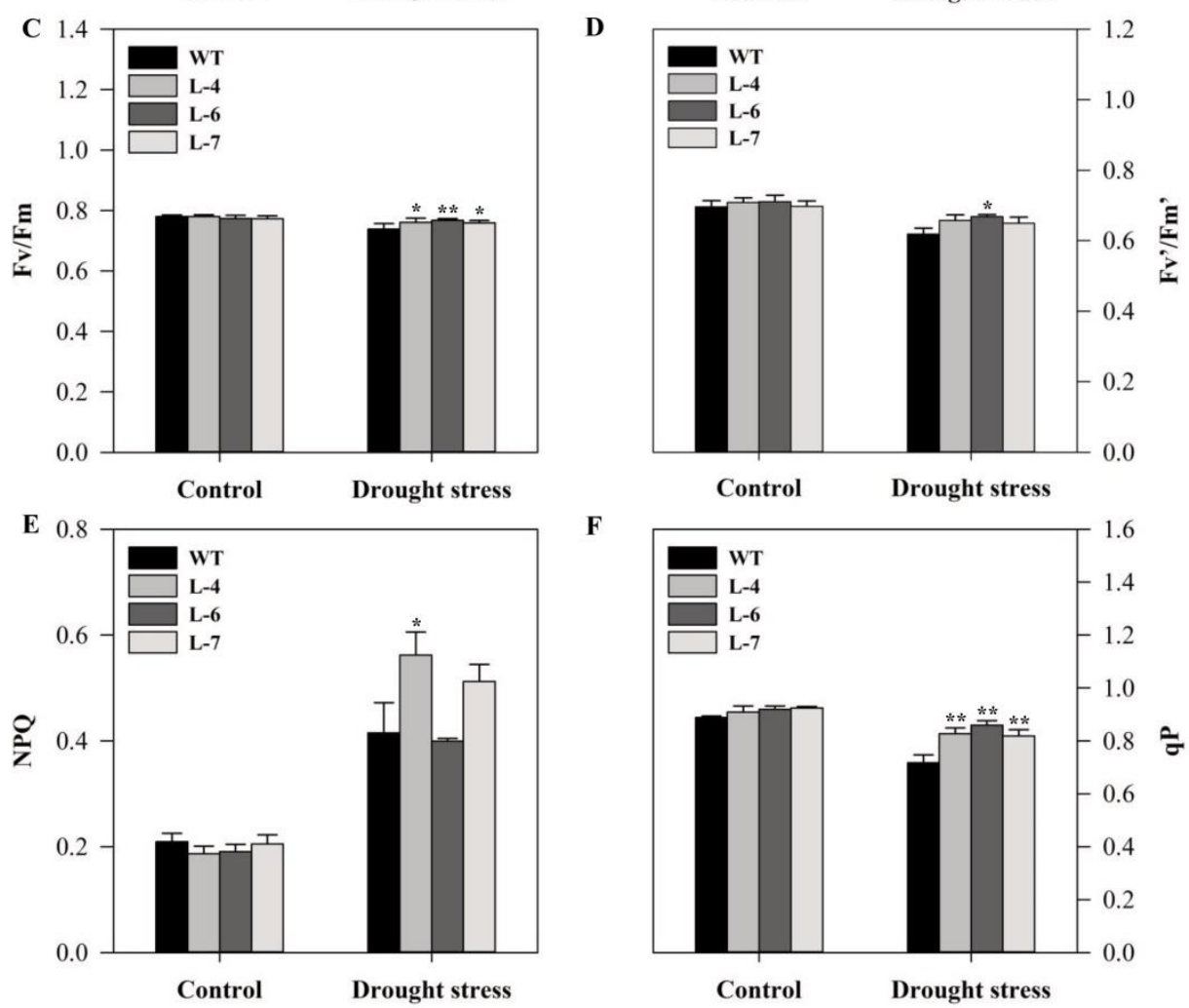

$\mathbf{F}$

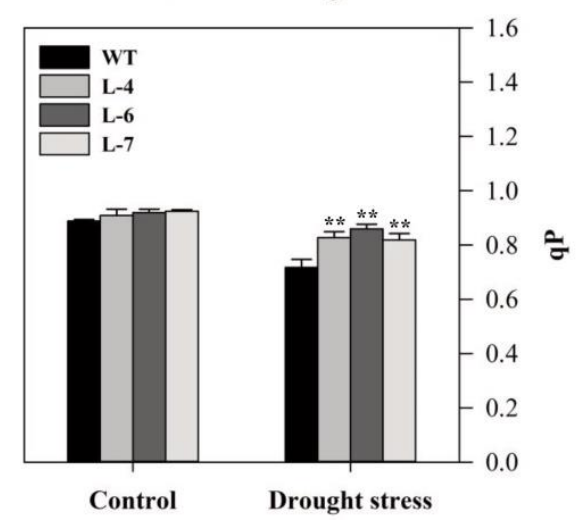

Figure 9. Overexpression of SIMAPK3 improved photosynthetic activity under drought stress. (A) chlorophyll content, (B) quantum efficiency of PSII photochemistry (øPSII), (C) the maximum photochemical efficiency of PSII $(F v / F m)$, (D) the efficiency of energy capture by open PSII reaction centers $\left(F v^{\prime} / F m^{\prime}\right),(E)$ non-photochemical quenching $(\mathrm{NPQ})$, and $(\mathbf{F})$ photochemical quenching $(\mathrm{qP})$. Two-months-old seedlings of WT and transgenic lines were subjected to drought stress by withholding water supply for 20 successive days and well-watered plants (watered every alternate day) served as control. Data represent mean $\pm \mathrm{SE}$ of three biological replicates. ${ }^{* *},{ }^{*}$ significant level differed at $p<0.01$ and $p<0.05$, respectively.

\subsection{Analysis of Antioxidant Enzyme Activity and Expression of Related Genes after Drought Stress}

Plants need an effective antioxidant system to scavenge or neutralize the excess ROS levels, thereby minimizing the oxidative damage during stress conditions. Therefore, the activities of antioxidant enzymes were measured in transgenic and WT seedlings under control and drought conditions. The 
results showed that the activities of all the antioxidant enzymes and content of proline were statistically similar under normal conditions in all lines except SOD, which was statistically higher in L-4 than that in WT (Figure 10A-E). After drought treatment, activities of those four antioxidant enzymes increased in both WT and transgenic plants, but transgenic lines had significantly higher activities than wild-type. In SIMAPK3 overexpressing plants, SOD, POD, CAT, and Ascorbate peroxidase (APX) activities, as well as proline content, were $93.96 \%, 16.91 \%, 7.2 \%, 14.22 \%$, and $22.9 \%$, respectively higher than WT (Figure 10A-E). To better understand the molecular mechanisms of SIMAPK3-mediated drought tolerance, transcript levels of ROS detoxification -related genes such as SISOD, SIPOD, SICAT, and SIAPX were examined after 15 days of drought stress (Figure 10F-I). qRT-PCR results showed that drought stress significantly induced the expression of all antioxidants related genes in transgenic plants as compared to WT, with the only exception for CAT in L-7, which was not statistically significant (Figure 10F-I).
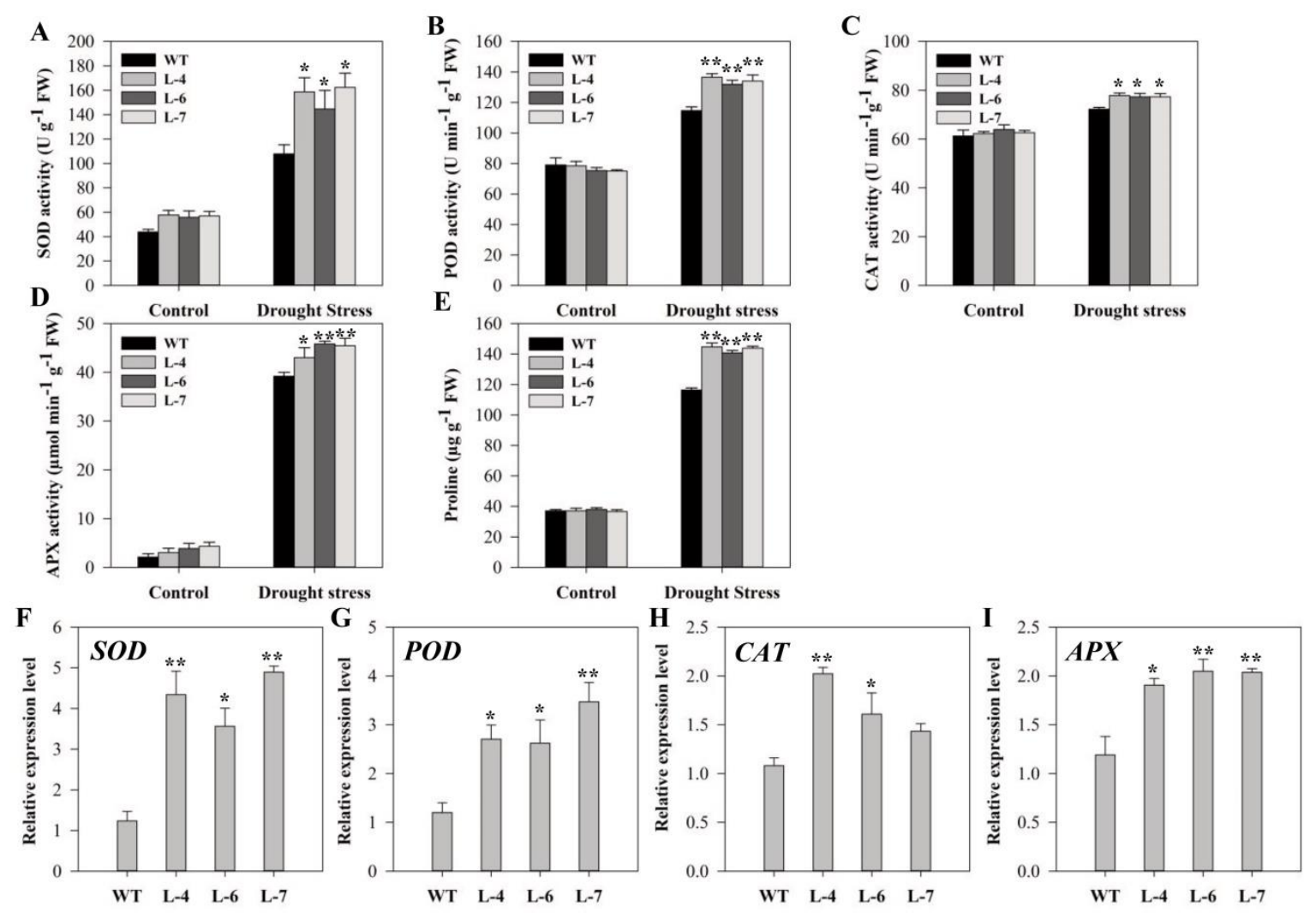

Figure 10. Comparison of enzymatic activity and relative expression of stress-responsive genes in wild-type and transgenic plants under normal and drought stress conditions. (A-D) Activity of SOD, POD, CAT, and APX, respectively. (E) Proline content and expression analysis of (F) SISOD, (G) SIPOD, (H) SICAT, and (I) SlAPX. Six-week old seedlings of WT and transgenic lines were subjected to drought stress by withholding water supply for 15 successive days and well-watered plants (watered every alternate day) served as a control. Data represent mean \pm SE of three biological replicates. ** * significant level differed at $p<0.01$ and $p<0.05$, respectively.

\section{Discussion}

Since germination to subsequent development, plants face various biotic and abiotic stresses throughout their life cycles. Depending on the severity of the stressors, a stress condition not only affects plant growth and development but also limits agricultural productivity. In the past, traditional breeding methods have been practiced to reduce various stress-related losses but due to the complexity in plant stress tolerance mechanism, only a minimum goal was achieved [36]. Recently, molecular and genetic engineering are being considered as the most effective approaches for the development of 
stress-tolerant crops. These advanced techniques unfold the physiological and biochemical pathways responsible for natural plant tolerance against stresses. MAPKs cascades are vital for plant growth, development and stress responses [13]. For instance, OsMPK5 in rice is an ortholog of AtMPK3 and NtWIPK in Arabidopsis and tobacco, respectively, can be activated by various biotic and abiotic stressors [37,38]. In addition, to stress-responsive signaling, AtMPK3 and AtMPK6, participate in stomatal patterning and development [39]. Despite a significance number of studies of different biochemical pathways relating to plant stress tolerance, molecular mechanisms that underlie stress perception and responses, especially $\mathrm{Cd}^{2+}$ remain poorly understood. Here, we demonstrated that overexpression of SIMAPK3 enhanced tolerance to $\mathrm{Cd}^{2+}$ and drought stress in tomato.

In this study, SIMAPK3 was cloned and overexpressed in tomato to study its role in plant tolerance to cadmium and drought stress. Tomato SIMAPK3 is located on chromosome 6, and contains 1122-bp ORF, 373 aa sequence and $5.25 \mathrm{Pls}$ theoretical isoelectric point. This gene is a member of group A and contains a serine/threonine protein kinases catalytic domain. The quantitative real-time PCR (qRT-PCR) analysis showed differential SIMAPK3 expression in various tissues (Figure 1A), whereas cadmium and drought stress treatment significantly increased transcript levels of SIMAPK3 (Figure 1B). Previous reports have shown that SIMPK3 and SIMPK7 are stimulated by various stress conditions such as drought, low temperature, and signaling molecules [40,41]. Similarly, high concentrations of cadmium ions activate four different MAPKs (SAMAK, SIMK, MMK2 and MMK3) and induce different cellular mechanisms [42]. In rice, $\mathrm{Cd}^{2+}$-induce activation of $42 \mathrm{kDa}$ MAP kinase, which shows activity of OsMPK3 and OsMPK6 [2], indicating the possible role of SlMAPK3 in tomato growth, development and stress tolerance.

Notably, exposure of plants to $\mathrm{Cd}^{2+}$ stress can cause morphological and physiological changes in the stressed plants. At the morphological level, symptoms of $\mathrm{Cd}^{2+}$ toxicity include chlorosis of leaves and inhibition of root growth $[43,44] . \mathrm{Cd}^{2+}$ administration induces expression of OsMAPK2 and significantly decreases root fresh weight and dry weight in rice seedlings [45]. Similarly, in Arabidopsis, AtOXI1 a serine-threonine kinase is induced by various stimuli, which is also required for the activation of $A t M P K-3,-6$ and root hair growth [46]. From the previous reports, it can be concluded that serine/threonine kinase has important functions in maintaining root morphology during stress conditions. In the current study, we found that seed germination rate and length of hypocotyl and epicotyl was more in transgenic than WT plants after $\mathrm{Cd}^{2+}$ stress (Figure 3B-D). Furthermore, $\mathrm{Cd}^{2+}$ stress reduced the chlorophyll content in all plants but symptoms of chlorosis were more severe in WT as compared to transgenic plants (Figure 4B-C). Similarly, transgenic lines showed improved roots morphological characteristics and root activity under 7- and 14-days $\mathrm{Cd}^{2+}$ stress compared to WT (Figure 5). In plants, cadmium initially accumulates in roots and some $\mathrm{Cd}^{2+}$ ions are also transported to shoots. This accumulation of $\mathrm{Cd}^{2+}$ causes toxicity that results in growth inhibition and damage to different plant organs [47]. Liu et al. [48] described that high $\mathrm{Cd}^{2+}$ accumulation activates MAPK and its transcription factors, resulting in cellular response to overcome $\mathrm{Cd}^{2+}$ toxicity. This result supported the positive role of SIMAPK3 overexpression against $\mathrm{Cd}^{2+}$ stress.

Similar to $\mathrm{Cd}^{2+}$ stress, drought stress affects many physiological and metabolic processes including photosynthesis, respiration, and overall plant growth. In the current study, SIMAPK3 overexpression enhanced the tolerance to drought stress in transgenic tomato as reflected by the germination rate and the phenotype of mature plants under drought stress (Figure 7A,B and Figure 8A). Furthermore, transgenic plants showed a reduced leaf water loss rate and improved RWCs as compared to that of WT (Figure 7C,E). Minimization of water loss is essential for the plant to survive under drought conditions. Transpiration, an essential physiological process by which water is transported to leaves and released through stomata, is considered the main pathway of water loss in plants. ABA as a signal molecule observes stresses and activates changes in guard cells to close stomata, thus preventing excessive water loss through transpiration [49]. In our study, ABA up-regulated SIMAPK3 expression level within $1 \mathrm{~h}$ of application (Figure S2A). These results in agreement with previous reports, which showed that SIMAPK3 and ZmSIMK1 expressions were up-regulated upon ABA treatment and overexpression 
of these protein kinases resulted in increased expression of ABA biosynthesis genes [35,50], while silencing of SIMPK4 and NtMPK4L genes resulted in reduced drought tolerance due to enhanced stomatal opening-induced rapid transpiration and subsequent wilting under drought stress [51,52]. These results showed that SIMAP3 might be involved in ABA-mediated stomatal closure in plants adaptation to drought conditions.

Drought stress causes an imbalance between light capture and utilization and inhibits photosynthetic activity in plants [53]. The inhibition of PSII activity leads to changes in quantum yield due to an imbalance between electron generation and utilization [54]. Furthermore, under drought conditions, chlorophyll content and chlorophyll fluorescence gradually decrease in A. thaliana [55]. In line with this, we found that drought stress decreased chlorophyll content and chlorophyll fluorescence in all lines. However, the fluorescence parameters, $\varnothing \mathrm{PSII}, \mathrm{Fv} / \mathrm{Fm}, \mathrm{Fv} / \mathrm{Fm} \mathrm{m}^{\prime}$ and $\mathrm{qP}$ were more sensitive in WT than in the transgenic lines (Figure 9). These results are in agreement with Ziaf et al. [56] who also observed similar changes in chlorophyll fluorescence in tobacco plants overexpressing a drought responsive gene.

Interestingly, the value of NPQ increased after drought stress and was significantly higher in SIMAPK3 overexpressed lines (Figure 9E). Plants under water stress efficiently dissipate energy trapped at PSII in the form of heat [57], the dissipation process start after increase in photosystem II S protein (PsbS) level during long-term water stress. PsbS is a small subunit of PSII and plays a key role in energy dissipation [58]. The PsbS protein induces the elevation of NPQ after binding to LHCII trimers with concomitant rearrangements $[59,60]$. The rise in NPQ in drought stress might also be due to stomata closure that inhibits the availability of carbon dioxide $\left(\mathrm{CO}_{2}\right)$ in the leaf chloroplasts [61], and NPQ has a protective role against photo-inhibition. It can be concluded that SIMAPK3 overexpression not only increased chlorophyll content but also improved photosynthetic activity compared to WT after drought stress.

Environmental stress causes oxidative damage to different cellular components and ultimately impairs membrane integrity [62,63]. Membrane integrity can be estimated by REL and MDA accumulation [64,65]. In the current study, the stress-induced EL percentage and MDA content were significantly lower in overexpressed plants compared to WT (Figures 4D, 7D and 8C), indicating that the SIMAPK3 overexpression attenuated membrane damage in transgenic lines. It was previously shown that wheat MAP kinase phosphatase 1 reduced MDA content in Arabidopsis after stress [66]. Similarly, SIMPK7 overexpression in transgenic tomato alleviates stress-induced relative electrolyte leakage and MDA content through activation of the cellular antioxidant systems and stress-associated genes [41].

ROS such as $\mathrm{H}_{2} \mathrm{O}_{2}$ and $\mathrm{O}_{2}{ }^{-}$, accumulated in plant tissue either cause oxidative damage at high concentration, or function as secondary messengers at low concentrations to mediate essential plant growth and developmental processes. Therefore, plants try to maintain a steady-state of ROS through collaboration between ROS production and elimination [67]. $\mathrm{H}_{2} \mathrm{O}_{2}$ is considered as one of the most stable ROS species and the $\mathrm{H}_{2} \mathrm{O}_{2}$ production is triggered by $\mathrm{Cd}^{2+}$ and drought stresses in plants $[68,69]$. An increase in $\mathrm{H}_{2} \mathrm{O}_{2}$ level was observed in leaves of both $\mathrm{WT}$ and transgenic lines under $\mathrm{Cd}^{2+}$ and dehydration stresses. However, SIMAPK3 overexpressing lines accumulated relatively lower levels of $\mathrm{H}_{2} \mathrm{O}_{2}$ than WT (Figures $4 \mathrm{E}$ and $8 \mathrm{~B}$ ), which is consistent with previous reports on protein kinase regulated scavenging of ROS during drought stress [70]. $\mathrm{Cd}^{2+}$-activated AtMAPK3 are effectively inhibited by pre-treatment with glutathione (ROS scavenger), further supporting the possible interaction of $\mathrm{Cd}^{2+}$ singling, ROS accumulation, and MAPK3 activation [48].

To alleviate ROS levels, plants enhanced the activity of various antioxidant enzymes that contribute to ROS scavenging and detoxification [71,72]. The current study showed that SIMAPK3 overexpression induced antioxidant enzymes activities in transgenic lines compared to that of WT after $\mathrm{Cd}^{2+}$ and drought stresses (Figures 6 and 10). Here, prolonged $\mathrm{Cd}^{2+}$ stress inhibited the POD activity in all lines and this decrease might be due to that the of severe $\mathrm{Cd}^{2+}$ stress on plants defense mechanisms leading to reduced protein synthesis [73]. Soudek et al. [74] also described the reduction 
of POD activity under high $\mathrm{Cd}^{2+}$ stress in Sorghum species. Similarly, SlMAPK3 overexpression induced up-regulation of the transcript level of $S O D, P O D, C A T$ and $A P X$ under stress conditions in transgenic lines, which showed a post-transcriptional effect on the induction and activity of ROS scavenging enzyme. Previous reports have shown that overexpression of different MAPKs cascade genes improves ROS homeostasis through activation of antioxidant systems or modifying transcriptional levels of various stress-associated genes [75,76]. Proline and sugar are important bio-macromolecules that play an essential role in plant development, stress tolerance, improve plant signaling, balancing cell redox status, cellular and osmotic adjustment and scavenging of ROS [77-79]. Changes in proline and soluble sugars have often been reported in plants exposed to harsh conditions, however, the current investigation showed that SIMAPK3 overexpression have role in additive up-regulation of the accumulation of proline and soluble sugar in overexpressed plants, suggesting that MAPK3 also improved the compatible solutes mechanism involved in ROS scavenging. The results are in line with Pan et al. [76], who reported the involvement of MAPKs in the accumulation of proline and soluble sugar during stress conditions. Taken together, these findings suggested that SIMAPK3 improves stress tolerance by regulating ROS-scavenging mechanism under stress conditions.

In summary, we found that $\mathrm{Cd}^{2+}$ and drought affect plant growth and development by altering various physiological and molecular mechanisms. The $\mathrm{Cd}^{2+}$ and drought-induced oxidative stress was attributed to an increased accumulation of ROS in tomato plants. SIMAPK3 overexpression alleviated the toxic effects of $\mathrm{Cd}^{2+}$ by improving root morphology and antioxidant activity, whereas elevation of photosynthetic activity, antioxidant system osmoprotectants conferred drought tolerance in transgenic plants. These findings also suggest that there might be an interaction of SIMAPK3 activation with $\mathrm{H}_{2} \mathrm{O}_{2}$ and $\mathrm{ABA}$ in $\mathrm{Cd}^{2+}$ and drought stress, respectively. Thus, we conclude that MAPKs-cascade has an important role in enhancing plant tolerance to different abiotic stressors, however, further studies on upstream to downstream kinases are required to better understand the complete pathways for $\mathrm{Cd}^{2+}$ and drought tolerance in plants.

\section{Materials and Methods}

\subsection{Plant Materials, Growth Conditions, and Treatments}

In the present study, Solanum lycopersicum L. cv. M82, was used to study the expression patterns of SIMPK3 gene. Tomato seeds were sown in pots containing a mixture of soil, peat, and vermiculite. The seedlings were grown in a growth chamber with a $16 / 8 \mathrm{~h}$ light/dark photoperiod at $25^{\circ} \mathrm{C}$, relative humidity of $70-80 \%$ with $200 \mu \mathrm{mol} \mathrm{m} \mathrm{m}^{-2} \mathrm{~s}^{-1}$ light intensity.

\subsection{Tissue Specific Expression Analysis of SlMPK3 Gene}

For tissue specific expression analysis, samples of stems, leaves, roots, flowers, fruits, and seeds were harvested from tomato plants. More specifically, root, stem and leaves samples were collected from five-week old plants, whereas fruits at the mature green stage and flowers at anthesis stage were sampled. All the collected samples were initially frozen in liquid nitrogen and stored at $-80{ }^{\circ} \mathrm{C}$ until isolation of RNA for qRT-PCR analysis.

\subsection{SIMPK3 Expression Analysis under Abiotic Stress and Hormonal Treatment}

Six-week old tomato plants were used to assess the changes in SIMPK3 expression in response to different abiotic stressors (cadmium, drought, salt and heat,) and hormonal treatments (ABA, SA and MeJA). For the imposition of cadmium stress, seedlings were uprooted, and thoroughly washed with tap water and transferred to full-strength Hoagland's solution for $48 \mathrm{~h}$ and then shifted to a similar solution containing $150 \mu \mathrm{M} \mathrm{Cd}^{2+}$. Meanwhile, a group of seedlings was dehydrated on filter paper to impose drought treatment. For salt stress, seedlings were irrigated with $200 \mathrm{mM} \mathrm{NaCl}$, while heat stress was imposed by keeping the plants at $40{ }^{\circ} \mathrm{C}$ in a growth chamber. For hormonal treatment, $100 \mu \mathrm{M}$ ABA, MeJA or SA solutions were directly sprayed on to the foliar portion, and mock-treated 
plants were used as the control. Young top leaves of different plants were collected at various time points $(0,1,3,6,12$ and $24 \mathrm{~h})$ after the treatments and immediately frozen in nitrogen and stored at $-80{ }^{\circ} \mathrm{C}$ for RNA isolation.

\subsection{Abiotic Stress Tolerance Assay in SlMPK3 Overexpressing Lines}

$\mathrm{T}_{2}$ generation of SIMPK3 overexpressing (L-4, L-6, and L-7) and WT lines were used for cadmium and drought tolerance assay. For germination assay, seventy five seeds of WT and overexpressing lines per replication were germinated on half-strength MS medium supplemented with or without $100 \mu \mathrm{M}$ $\mathrm{Cd}^{2+}$ and $200 \mathrm{mM}$ mannitol. Germination was counted for seven days and seeds with radical length $2 \mathrm{~mm}$ long were considered germinated. Hypocotyl length of the thirty seedlings was measured with ruler from root/shoot junction to the point where cotyledon petioles branched. For cadmium tolerance assay, the uniform size seedlings of wild-type and transgenic lines at the fully expanded three-leaf stage were transferred into containers $(60 \times 20 \times 12 \mathrm{~cm})$ filled with basic Hoagland's nutrient media for hydroponic cultures. At fully expanded five-leaf stage plants were exposed to cadmium stress, the plants were grown in cadmium free medium for two weeks considered as $0 \mathrm{~d}$ stress, while for $7 \mathrm{~d}$ stress, plants were grown first for a week without cadmium prior to transfer to stress condition for a week and in $14 \mathrm{~d}$ stress condition, plants were immediately transferred to cadmium medium. Cadmium with a concentration of $100 \mu \mathrm{M}$ was used as $\mathrm{CdCl}_{2} 2.5 \mathrm{H}_{2} \mathrm{O}$ from already prepared stock solution in distilled water. The concentration of $\mathrm{CdCd}^{2+}$ was used according to the published reports [80,81]. The solution was renewed every week with or without $\mathrm{Cd}^{2+}$ for stress and control conditions, respectively. After fourteen days of stress condition, plants were harvested and the experiment was terminated. For molecular and physiological analysis, the harvested leaves were frozen in liquid nitrogen and kept at $-80^{\circ} \mathrm{C}$. Roots morphology was studied using "Epson Perfection V700" photo flatbed scanner and root activity, root fresh and dry weight were measured for control and stress-exposed plants.

For drought tolerance evaluation, the uniform-size seedlings of transgenic and WT lines were divided into two groups (control and drought groups). The control group was watered every second day, while drought treatment was imposed by withholding water for 15 days. Fifteen days after stress conditions, the topmost leaves from the tested plant were collected, frozen in liquid nitrogen and stored for further analysis. To determine water loss essay, the top second fully expanded leaves of both transgenic and WT lines were detached and placed on filter papers in the presence of white fluorescent light at room temperature. The harvested leaf samples were weighed after every thirty minutes of interval up to $7 \mathrm{~h}$ and measured as a percentage of the control. Chlorophyll fluorescence was examined after 30 min of dark adaptation in the third fully expanded leaves using PAM-2500 Portable Modulated Chlorophyll Fluorometer (Heinz Walz, Effeltrich, Germany). Notably, for this assay, about two months old transgenic and WT plants were subjected to drought conditions for 20 days to assess drought tolerance at the late vegetative stage.

\subsection{Phylogenetic and Protein Domain Analysis}

The amino acid sequences of SlMAPKs proteins were gained using NCBI (https:/ / www.ncbi.nlm. nih.gov/) online tool. The phylogenetic tree was generated using MEGA5 software (Pennsylvania State University, State College, USA) by Neighbor-Joining (NJ) method with a Poisson model and replicates test of 1000 bootstrap [82]. The protein domains were identified using the online Single Modular Architecture Tool, SMART (http://smart.embl-heidelberg.de/). All the proteins sequence information used was listed in Table S1.

\subsection{Vector Construction and Gene Transformation}

The full coding sequence of SIMPK3 was amplified from cDNAs by polymerase chain reaction (PCR) using specific primers (Table S2). The product was cloned into the pMD-18T vector and after sequencing, the correct pMD-18T-SlMPK3 was double digested using BamHI and SacI restriction sites. The product was ligated into plant expression vector pVBG2307 and the resulting construct 
was transformed into Agrobacterium tumefaciens strain GV3101. Standard leaf protocol was used for transformation of tomato [83]. Sterile cotyledons pieces from 10-12 days seedlings were transferred to Agrobacterium suspended MS solution $\left(\mathrm{OD}_{600}=0.5\right)$ containing acetosyringone for $15 \mathrm{~min}$ and then incubated for $48 \mathrm{~h}$ on MS media without antibiotics. The explants were transferred to MS selection media containing $50 \mathrm{mg} \mathrm{L}^{-1}$ kanamycin and $200 \mathrm{mg} \mathrm{L}^{-1}$ carbenicillin with proper amount of hormones. The shoots developed from the calli were shifted to rooting media containing $30 \mathrm{mg} \mathrm{L}^{-1}$ kanamycin and $200 \mathrm{mg} \mathrm{L}^{-1}$ carbenicillin. The kanamycin resistance plants were further confirmed by genomic PCR using nptII forward and SIMAPK3 reverse primers. Seeds were harvested from inbred lines and transgenic $\mathrm{T}_{2}$ lines were used for further experiments.

\subsection{RNA Isolation and Real-Time $q R T-P C R$}

Total RNA was isolated using Trizol reagent (Invitrogen, Carlsbad, CA, USA) and cDNA was synthesized using Takara Prime Script RT reagent Kit (Takara, Dalian, China). Thermo cycler iQ5 Real-Time PCR Detection System (BIO-RAD Corp., Hercules, CA, USA) and SYBR Premix Ex TaqTM (Takara, Dalian, China) were used following manufacturer guidelines to run qRT-PCR. The PCR conditions were: $95^{\circ} \mathrm{C}$ for $1 \mathrm{~min}$, followed by 40 cycles of $95^{\circ} \mathrm{C}$ for $10 \mathrm{~s}, 55^{\circ} \mathrm{C}$ for $10 \mathrm{~s}$ and $72{ }^{\circ} \mathrm{C}$ for $20 \mathrm{~s}$. Tomato actin gene was used as an internal control. All the primers used in the experiment are listed in Table S2. The $2^{-\Delta \Delta C T}$ method was applied to analyze the PCR data [84].

\subsection{Root Activity Assay}

Root activity of the stressed and un-stressed plants was measured using triphenyltetrazolium chloride (TTC) method [85]. Roots from stressed and un-stressed plants were collected and washed with distilled water. $0.2 \mathrm{~g}$ of roots tips were cut $(1 \mathrm{~cm})$ and dried on clean filter papers. The dried tips were placed in tubes and soaked with a mixture of TTC $(1 \%)$ and phosphate buffer $(0.1 \mathrm{M}-\mathrm{pH}$ 7.0) solution at $37^{\circ} \mathrm{C}$ for $2 \mathrm{~h}$ in dark. The reaction was stopped by adding of sulfuric acid (5\%, $\mathrm{H}_{2} \mathrm{SO}_{4}$ ) after $2 \mathrm{~h}$ incubation. The roots tip were collected and dried again on filter papers. Roots were ground with $5 \mathrm{~mL}$ ethyl-acetate and certain amount quartz sand in mortar and pestle to extract the triphenyl formazan (TTF). The final volume of the extract was diluted with ethyl-acetate to $10 \mathrm{~mL}$. Absorption was taken at $485 \mathrm{~nm}$ and reduced TTC was calculated from the standard curve. TTC reduction intensity $\left(\mathrm{mg} \mathrm{g}^{-1} \mathrm{~h}^{-1}\right)=$ TTC reduced $/ \mathrm{FW} \mathrm{h}$, where FW and $\mathrm{h}$ is root fresh weight and incubation time respectively.

\subsection{Measurement of Leaf Water Content and Electrolyte Leakage}

RWC was measured as described by Shekhawat et al. [86]. Leaves from WT and transgenic lines were harvested and immediately weighed for fresh weight (FW). Next, the leaves were floated on de-ionized water at $4{ }^{\circ} \mathrm{C}$ for overnight to measure the turgid weight (TW). For dry weight (DW) analysis, the leaves were dried in a hot oven for 2 days at $60-62{ }^{\circ} \mathrm{C}$. Water content was calculated as: $\mathrm{RWC}=(\mathrm{FW}-\mathrm{DW}) /(\mathrm{TW}-\mathrm{DW}) \times 100$. Electrolyte leakage was determined according to the protocol of Compose et al. [87]. The fourth fully expanded leaves of WT and transgenic plants were excised from well-watered and drought-stressed plants. The leaves were first rinsed with distilled water and then fifteen leaf discs (diameter, $8 \mathrm{~mm}$ ) were punched. The leaf discs were immersed in $25 \mathrm{~mL}$ distilled water containing tubes and were shaken at $300 \times g$ at $25^{\circ} \mathrm{C}$ for $4 \mathrm{~h}$ in dark. After $4 \mathrm{~h}$ of incubation, the electrolyte leakage (EC1) of the solutions was recorded. The leaf discs solutions were then boiled for $20 \mathrm{~min}$, cooled down at room temperature and then electrolyte leakage (EC2) of the solutions was recorded again. Relative electrolyte leakage (\%) was measured using a conductivity detector and results obtained as: $(\mathrm{EC} 1 / \mathrm{EC} 2) \times 100$.

\subsection{Determination of Chlorophyll, Soluble Sugar and Proline Content}

Chlorophyll content was determined in leaves using $80 \%$ acetone. The fresh leaves from stressed and control plants were incubated overnight in $80 \%$ acetone and the leaf pigments were retained. The 
absorbance was taken at 663 and $646 \mathrm{~nm}$ and chlorophyll content were measured in milligrams per gram FW [88]. Soluble sugar content was analyzed with anthrone colorimetry [89]. About $0.2 \mathrm{~g}$ leaf samples (small pieces) were boiled in $10 \mathrm{~mL}$ distilled water for $30 \mathrm{~min}$. The liquid extract was separated in $25 \mathrm{~mL}$ tube and repeated again. The extract was diluted to $25 \mathrm{~mL}$ final volume. Sample extract $(0.5 \mathrm{~mL})$ was mixed with distilled water $(1.5 \mathrm{~mL}), 2 \%(w / v)$ anthrone ethyl acetate reagent $(0.5 \mathrm{~mL})$ and $100 \% \mathrm{H}_{2} \mathrm{SO}_{4}(5 \mathrm{~mL})$. The mixture was boiled again for $10 \mathrm{~min}$ and after cooling, absorbance was recorded at $630 \mathrm{~nm}$. The amount of soluble sugar was calculated from a standard curve of known amounts of glucose. Proline was measured as the protocol described by Zhang et al. [90]. Leaf sample $(0.3 \mathrm{~g})$ was boiled with $3 \%$ sulphosalicylic acid $(5 \mathrm{~mL})$ for $10 \mathrm{~min}$ at $100{ }^{\circ} \mathrm{C}$. The mixture was filtered and filtrate $(2 \mathrm{~mL})$ was mixed with acid ninhydrin reagent $(2 \mathrm{~mL})$ and glacial acetic acid $(2 \mathrm{~mL})$. The combined mixture was heated again for $40 \mathrm{~min}$ at $100{ }^{\circ} \mathrm{C}$ and reaction was terminated in an ice bath. Finally, cooled mixture was treated with toluene $(5 \mathrm{~mL})$ and the absorbance of upper organic phase was determined at $520 \mathrm{~nm}$. Proline content was measured from the standard curve of known amounts of proline.

\subsection{Determination of $\mathrm{H}_{2} \mathrm{O}_{2}$ Content and Histochemical Detection of $\mathrm{H}_{2} \mathrm{O}_{2}$}

The $\mathrm{H}_{2} \mathrm{O}_{2}$ content was measured according to Sergiev et al. [91]. Leaf samples (0.5 g) were homogenized in ice bath with trichloroacetic acid (TCA) $0.1 \%(w / v)$ solution. The homogenate was centrifuged for $15 \mathrm{~min}$ at $12,000 \times g$ and the supernatant was added to $1 \mathrm{M}$ potassium iodide and $10 \mathrm{mM}$ potassium phosphate buffer $\mathrm{pH}$ 7.0. The solution was briefly mixed and absorbance was recorded at $390 \mathrm{~nm}$. The $\mathrm{H}_{2} \mathrm{O}_{2}$ content was measured from the standard curve. Standard solutions for $\mathrm{H}_{2} \mathrm{O}_{2}$ curve were prepared by dilution of $100 \mu \mathrm{M} \mathrm{H}_{2} \mathrm{O}_{2}$ and $0.1 \%$ TCA in ration of 0:1, 0.1:0.9, 0.2:0.8, 0.4:0.6, 0.6:0.4, 0.8:0.2, and 1:0 $\mathrm{mL}$ in $3 \mathrm{~mL}$ of potassium phosphate buffer and potassium iodide solution. For in situ visualizations of $\mathrm{H}_{2} \mathrm{O}_{2}$ accumulation, leaflets of the second fully expanded leaves from stressed and control plants of WT and transgenic lines were used. The leaves were dipped in $1 \mathrm{mg} \mathrm{mL}^{-1} \mathrm{DAB}, \mathrm{pH} 3.8$ and incubated for $8 \mathrm{~h}$ in dark condition. For removal of chlorophyll, the DAB stained leaves were shifted to absolute ethanol and heated in a boiling water bath for $10 \mathrm{~min}$ [92].

\subsection{Assay of Lipid Peroxidation and Antioxidant Enzymes Activity}

Lipid peroxidation was estimated by analyzing MDA content according to Campos et al. [87]. About $0.5 \mathrm{~g}$ of leaf sample was ground in sodium phosphate buffer ( $\mathrm{pH} 7.8$ ) having $1 \%$ polyvinyl pyrrolidone (PVP) on an ice bath. The extract was centrifuged at $12,000 \times g$, for $20 \mathrm{~min}$ at $4{ }^{\circ} \mathrm{C}$ and the supernatant was mixed with 5\% TCA having 0.5\% 2-thiobarbituric acid (TBA) and boiled for $20 \mathrm{~min}$ at $95^{\circ} \mathrm{C}$ water bath. The solution was cooled, centrifuged at $5000 \mathrm{~g}$ for $10 \mathrm{~min}$ and then the absorbance was measured at 600, 532 and $450 \mathrm{~nm}$. Antioxidant enzymes activities were analyzed according to the protocol described by Guo et al. [93]. For SOD activity assay, the crude enzyme was further diluted with water containing $130 \mathrm{mM}$ methionine, $0.1 \mathrm{mM}$ EDTA-Na $2,0.75 \mathrm{mM}$ nitrogen blue tetrazolium (NBT), $0.02 \mathrm{mM}$ riboflavin, and $0.05 \mathrm{mM}$ phosphate buffer. Reaction mixture without enzymes was used as a control. All the reaction tubes and one control tube was placed in a light incubator at 4000 lux illumination for $20 \mathrm{~min}$ and covered with black fabric immediately, while another control tube was kept in dark. The activity was measured at $560 \mathrm{~nm}$. For POD activity, reaction mixture contained enzyme extract, $0.2 \%$ guaiacol and $0.3 \% \mathrm{H}_{2} \mathrm{O}_{2}$ diluted with $0.2 \mathrm{mM}$ phosphate buffer ( $\mathrm{pH}$ 7.0). The kinetic was recorded at $470 \mathrm{~nm}$ wavelength for $3 \mathrm{~min}$ reaction time. CAT activity was examined by observing the decrease in the activity of the enzyme. The extraction enzyme was mixed with $0.3 \%$ $\mathrm{H}_{2} \mathrm{O}_{2}$ diluted with $0.2 \mathrm{mM}$ phosphate buffer ( $\mathrm{pH} 7.0$ ) and activity was measured at $240 \mathrm{~nm}$ for $3 \mathrm{~min}$ every $30 \mathrm{sec}$. APX activity was analyzed according to the protocol of Jiang and Zhang [94]. The reaction mixture contained $0.1 \mathrm{mM} \mathrm{H}_{2} \mathrm{O}_{2}, 50 \mathrm{mM}$ potassium phosphate buffer ( $\mathrm{pH} 7.0$ ), $0.5 \mathrm{mM}$ ascorbate (ASC) and enzyme extract of $100 \mu \mathrm{L}$. The reaction was started by adding enzyme solution and activity was recorded at $290 \mathrm{~nm}$. All of the spectrophotometric measurements were performed on a UNICO WFZ 3802H UV/VIS spectrophotometer (UNICO, Shanghai, China). 


\subsection{Statistical Analysis}

SPSS 20.0 software (IBM, Armonk, New York, USA) was used for statistical analysis. A significant difference between WT and transgenic lines were determined using least significance difference (LSD) test. Means \pm SE were calculated from the average of three biological replicates. Asterisks * at $p<0.05$ and ${ }^{* *}$ at $p<0.01$ show different significance levels.

Supplementary Materials: The following are available online. Figure S1, Phylogenetic and structural analysis based on the amino acid sequences of Solanum lycopersicum SlMAPKs; Figure S2, Expression patterns of SIMAPK3 after different hormonal treatments; Figure S3, Confirmation of transgenic plants. Table S1, The protein sequence information used for phylogenetic tree construction and protein domain; Table S2, Primers used in the study.

Author Contributions: Conceptualization, T.M. and Y.L. (Yan Liang); Formal analysis, T.M., Y.M. and Y.L. (Yushun Li); Methodology, T.M. and J.Z.; Resources, Y.L. (Yan Liang); Supervision, Y.L. (Yan Liang); Writing-original draft, T.M. and F.Z.; Writing-review \& editing, Y.Z. and Y.L. (Yan Liang).

Funding: This work was supported by The National Key Research and Development Program of China (2016YFD0101703).

Acknowledgments: We thank to Golam Jalal Ahammed for editing this manuscript.

Conflicts of Interest: The authors declare no conflict of interest.

\section{References}

1. Schwarz, D.; Rouphael, Y.; Colla, G.; Venema, J.H. Grafting as a tool to improve tolerance of vegetables to abiotic stresses: Thermal stress, water stress and organic pollutants. Sci. Hortic. 2010, 127, $162-171$. [CrossRef]

2. Yeh, C.M.; Chien, P.S.; Huang, H.J. Distinct signalling pathways for induction of MAP kinase activities by cadmium and copper in rice roots. J. Exp. Bot. 2007, 58, 659-671. [CrossRef] [PubMed]

3. Gratão, P.L.; Monteiro, C.C.; Tezotto, T.; Carvalho, R.F.; Alves, L.R.; Peters, L.P.; Azevedo, R.A. Cadmium stress antioxidant responses and root-to-shoot communication in grafted tomato plants. BioMetals 2015, 28, 803-816. [CrossRef] [PubMed]

4. Iannone, M.F.; Groppa, M.D.; Benavides, M.P. Cadmium induces different biochemical responses in wild type and catalase-deficient tobacco plants. Environ. Exp. Bot. 2015, 109, 201-211. [CrossRef]

5. Fojtová, M.; Kovařík, A. Genotoxic effect of cadmium is associated with apoptotic changes in tobacco cells. Plant Cell Environ. 2000, 23, 531-537. [CrossRef]

6. Moradi, L.; Ehsanzadeh, P. Effects of Cd on photosynthesis and growth of safflower (Carthamus tinctorius L.) genotypes. Photosynthetica 2015, 53, 506-518. [CrossRef]

7. Djebali, W.; Zarrouk, M.; Brouquisse, R.; El Kahoui, S.; Limam, F.; Ghorbel, M.H.; Chaibi, W. Ultrastructure and lipid alterations induced by cadmium in tomato (Lycopersicon esculentum) chloroplast membranes. Plant Biol. 2005, 7, 358-368. [CrossRef]

8. Ali, B.; Huang, C.R.; Qi, Z.Y.; Ali, S.; Daud, M.K.; Geng, X.X.; Liu, H.B.; Zhou, W.J. 5-Aminolevulinic acid ameliorates cadmium-induced morphological, biochemical, and ultrastructural changes in seedlings of oilseed rape. Environ. Sci. Pollut. Res. 2013, 20, 7256-7267. [CrossRef]

9. Hu, Y.F.; Zhou, G.; Na, X.F.; Yang, L.; Nan, W.B.; Liu, X.; Zhang, Y.Q.; Li, J.L.; Bi, Y.R. Cadmium interferes with maintenance of auxin homeostasis in Arabidopsis seedlings. J. Plant Physiol. 2013, 170, 965-975. [CrossRef]

10. Reddy, A.R.; Chaitanya, K.V.; Vivekanandan, M. Drought-induced responses of photosynthesis and antioxidant metabolism in higher plants. J. Plant Physiol. 2004, 161, 1189-1202. [CrossRef]

11. Heidarvand, L.; Maali Amiri, R. What happens in plant molecular responses to cold stress? Acta Physiol. Plant. 2010, 32, 419-431. [CrossRef]

12. Tena, G.; Asai, T.; Chiu, W.-L.; Sheen, J. Plant mitogen-activated protein kinase signaling cascades. Curr. Opin. Plant Biol. 2001, 4, 392-400. [CrossRef]

13. Rodriguez, C.M.S.; Petersen, M.; Mundy, J. Mitogen-activated protein kinase signaling in plants. Annu. Rev. Plant Biol. 2010, 61, 621-649. [CrossRef] [PubMed]

14. Çakır, B.; Kılıçkaya, O. Mitogen-activated protein kinase cascades in Vitis vinifera. Front. Plant Sci. 2015, 6, 656. [CrossRef] [PubMed] 
15. Jonak, C.; Ligterink, W.; Hirt, H. MAP Kinases in plant signal transduction. Cell. Mol. Life Sci 1999, 55, 204-213. [CrossRef] [PubMed]

16. Wang, J.; Ding, H.; Zhang, A.; Ma, F.; Cao, J.; Jiang, M. A novel mitogen-activated protein kinase gene in maize (Zea mays), ZmMPK3, is involved in response to diverse environmental cues. J. Integr. Plant Biol. 2010, 52, 442-452. [CrossRef] [PubMed]

17. Kong, F.; Wang, J.; Cheng, L.; Liu, S.; Wu, J.; Peng, Z.; Lu, G. Genome-wide analysis of the mitogen-activated protein kinase gene family in Solanum lycopersicum. Gene 2012, 499, 108-120. [CrossRef]

18. Lee, S.; Hirt, H.; Lee, Y. Phosphatidic acid activates a wound-activated MAPK in Glycine max. Plant J. 2001, 26, 479-486. [CrossRef]

19. Mishra, N.S.; Tuteja, R.; Tuteja, N. Signaling through MAP kinase networks in plants. Arch. Biochem. Biophys. 2006, 452, 55-68. [CrossRef]

20. Li, Y.; Qin, L.; Zhao, J.; Muhammad, T.; Cao, H.; Li, H.; Zhang, Y.; Liang, Y. SIMAPK3 enhances tolerance to tomato yellow leaf curl virus (TYLCV) by regulating salicylic acid and jasmonic acid signaling in tomato (Solanum lycopersicum). PLoS ONE 2017, 12, e0172466. [CrossRef]

21. Xu, J.; Li, Y.; Wang, Y.; Liu, H.; Lei, L.; Yang, H.; Liu, G.; Ren, D. Activation of MAPK kinase 9 induces ethylene and camalexin biosynthesis and enhances sensitivity to salt stress in Arabidopsis. J. Biol. Chem. 2008, 283, 26996-27006. [CrossRef] [PubMed]

22. Yoo, S.D.; Cho, Y.H.; Tena, G.; Xiong, Y.; Sheen, J. Dual control of nuclear EIN3 by bifurcate MAPK cascades in $\mathrm{C}_{2} \mathrm{H}_{4}$ signalling. Nature 2008, 451, 789-795. [CrossRef] [PubMed]

23. Zhou, C.; Cai, Z.; Guo, Y.; Gan, S. An Arabidopsis mitogen-activated protein kinase cascade, MKK9-MPK6, plays a role in leaf senescence. Plant Physiol. 2009, 150, 167-177. [CrossRef] [PubMed]

24. Lei, L.; Li, Y.; Wang, Q.; Xu, J.; Chen, Y.; Yang, H.; Ren, D. Activation of MKK9-MPK3/MPK6 enhances phosphate acquisition in Arabidopsis thaliana. New Phytol. 2014, 203, 1146-1160. [CrossRef] [PubMed]

25. Teige, M.; Scheikl, E.; Eulgem, T.; Dóczi, R.; Ichimura, K.; Shinozaki, K.; Dangl, J.L.; Hirt, H. The MKK2 pathway mediates cold and salt stress signaling in Arabidopsis. Mol. Cell 2004, 15, 141-152. [CrossRef] [PubMed]

26. Ichimura, K.; Mizoguchi, T.; Yoshida, R.; Yuasa, T.; Shinozaki, K. Various abiotic stresses rapidly activate Arabidopsis MAP kinases ATMPK4 and ATMPK6. Plant J. 2000, 24, 655-665. [CrossRef] [PubMed]

27. Droillard, M.J.; Boudsocq, M.; Barbier-Brygoo, H.; Laurière, C. Different protein kinase families are activated by osmotic stresses in Arabidopsis thaliana cell suspensions: Involvement of the MAP kinases AtMPK3 and AtMPK6. FEBS Lett. 2002, 527, 43-50. [CrossRef]

28. Zhang, S.; Klessig, D.F. Resistance gene N-mediated de novo synthesis and activation of a tobacco mitogen-activated protein kinase by tobacco mosaic virus infection. Proc. Natl. Acad. Sci. USA 1998, 95, 7433-7438. [CrossRef]

29. Chen, Y.Y.; Lin, Y.M.; Chao, T.C.; Wang, J.F.; Liu, A.C.; Ho, F.I.; Cheng, C.P. Virus-induced gene silencing reveals the involvement of ethylene-, salicylic acid- and mitogen-activated protein kinase-related defense pathways in the resistance of tomato to bacterial wilt. Physiol. Plant. 2009, 136, 324-335. [CrossRef]

30. Lin, K.C.; Sun, P.C.; Lin, P.L. Production of reactive oxygen species and induction of signaling pathways for the ACO gene expressions in tomato plants triggered by the volatile organic compound ether. Plant Cell Rep. 2011, 30, 599-611. [CrossRef]

31. Higgins, R.; Lockwood, T.; Holley, S.; Yalamanchili, R.; Stratmann, J.W. Changes in extracellular pH are neither required nor sufficient for activation of mitogen-activated protein kinases (MAPKs) in response to systemin and fusicoccin in tomato. Planta 2007, 225, 1535-1546. [CrossRef] [PubMed]

32. Stulemeijer, I.J.E.; Stratmann, J.W.; Joosten, M.H.A.J. Tomato mitogen-activated protein kinases LeMPK1, LeMPK2, and LeMPK3 are activated during the Cf-4/Avr4-induced hypersensitive response and have distinct phosphorylation specificities. Plant Physiol. 2007, 144, 1481-1494. [CrossRef] [PubMed]

33. Mayrose, M.; Bonshtien, A.; Sessa, G. LeMPK3 is a mitogen-activated protein kinase with dual specificity induced during tomato defense and wounding responses. J. Biol. Chem. 2004, 279, 14819-14827. [CrossRef] [PubMed]

34. Li, C.; Yan, J.M.; Li, Y.Z.; Zhang, Z.C.; Wang, Q.L.; Liang, Y. Silencing the SpMPK1, SpMPK2, and SpMPK3 genes in tomato reduces abscisic acid-mediated drought tolerance. Int. J. Mol. Sci. 2013, 14, 21983-21996. [CrossRef] [PubMed] 
35. Li, C.; Chang, P.P.; Ghebremariam, K.M.; Qin, L.; Liang, Y. Overexpression of tomato SpMPK3 gene in Arabidopsis enhances the osmotic tolerance. Biochem. Biophys. Res. Commun. 2014, 443, 357-362. [CrossRef] [PubMed]

36. Munir, S.; Liu, H.; Xing, Y.; Hussain, S.; Ouyang, B.; Zhang, Y.; Li, H.; Ye, Z. Overexpression of calmodulin-like (ShCML44) stress-responsive gene from Solanum habrochaites enhances tolerance to multiple abiotic stresses. Sci. Rep. 2016, 6, 31772. [CrossRef] [PubMed]

37. Zhang, S.; Klessig, D.F. MAPK cascades in plant defense signaling. Trends Plant Sci. 2001, 6, $520-527$. [CrossRef]

38. Hamel, L.; Nicole, M.; Sritubtim, S.; Ellis, M.; Ehlting, J.; Beaudoin, N.; Barbazuk, B.; Klessig, D.; Lee, J.; Martin, G.; et al. Ancient signals: Comparative genomics of plant MAPK and MAPKK gene families. Trends Plant Sci. 2006, 11, 192-198. [CrossRef]

39. Wang, H.; Ngwenyama, N.; Liu, Y.; Walker, J.C.; Zhang, S. Stomatal development and patterning are regulated by environmentally responsive mitogen-activated protein kinases in Arabidopsis. Plant Cell 2007, 19, 63-73. [CrossRef]

40. Yu, L.; Yan, J.; Yang, Y.; Zhu, W. Overexpression of tomato mitogen-activated protein kinase SlMPK3 in tobacco increases tolerance to low temperature stress. Plant Cell. Tissue Organ Cult. 2015, 121, 21-34. [CrossRef]

41. Yu, L.; Yan, J.; Yang, Y.; He, L.; Zhu, W. Enhanced tolerance to chilling stress in tomato by overexpression of a mitogen-activated protein kinase, SlMPK7. Plant Mol. Biol. Report. 2016, 34, 76-88. [CrossRef]

42. Jonak, C.; Nakagami, H.; Hirt, H. Heavy metal stress. Activation of distinct mitogen-activated protein kinase pathways by copper and cadmium. Plant Physiol. 2004, 136, 3276-3283. [CrossRef] [PubMed]

43. Wojcik, M.; Tukendorf, A. Cd- tolerance of maize, rye and wheat seedlings. Acta Physiol. Plant. 1999, 21, 99-107. [CrossRef]

44. Nocito, F.F.; Pirovano, L.; Cocucci, M.; Sacchi, G.A.; Vegetale, P.; Celoria, V. Cadmium-induced sulfate uptake in maize roots. Plant Physiol. 2002, 129, 1872-1879. [CrossRef] [PubMed]

45. Yeh, C.M.; Hsiao, L.J.; Huang, H.J. Cadmium activates a mitogen-activated protein kinase gene and MBP kinases in rice. Plant Cell Physiol. 2004, 45, 1306-1312. [CrossRef] [PubMed]

46. Rentel, M.C.; Lecourieux, D.; Ouaked, F.; Usher, S.L.; Petersen, L.; Okamoto, H.; Knight, H.; Peck, S.C.; Grierson, C.S.; Hirt, H.; et al. OXI1 kinase is necessary for oxidative burst-mediated signalling in Arabidopsis. Nature 2004, 427, 858-861. [CrossRef] [PubMed]

47. Lunáčková, L.; Masarovičová, E.; Král'Ová, K.; Streško, V. Response of fast growing woody plants from family salicaceae to cadmium treatment. Bull. Environ. Contam. Toxicol. 2003, 70, 576-585. [CrossRef]

48. Liu, X.M.; Kim, K.E.; Kim, K.C.; Nguyen, X.C.; Han, H.J.; Jung, M.S.; Kim, H.S.; Kim, S.H.; Park, H.C.; Yun, D.J.; et al. Cadmium activates Arabidopsis MPK3 and MPK6 via accumulation of reactive oxygen species. Phytochemistry 2010, 71, 614-618. [CrossRef]

49. Raghavendra, A.S.; Gonugunta, V.K.; Christmann, A.; Grill, E. ABA perception and signalling. Trends Plant Sci. 2010, 15, 395-401. [CrossRef]

50. Wang, L.; Liu, Y.; Cai, G.; Jiang, S.; Pan, J.; Li, D. Ectopic expression of ZmSIMK1 leads to improved drought tolerance and activation of systematic acquired resistance in transgenic tobacco. J. Biotechnol. 2014, 172, 18-29. [CrossRef]

51. Virk, N.; Liu, B.; Zhang, H.; Li, X.; Zhang, Y.; Li, D.; Song, F. Tomato SlMPK4 is required for resistance against Botrytis cinerea and tolerance to drought stress. Acta Physiol. Plant. 2013, 35, 1211-1221. [CrossRef]

52. Yanagawa, Y.; Yoda, H.; Osaki, K.; Amano, Y.; Aono, M.; Seo, S.; Kuchitsu, K.; Mitsuhara, I. Mitogen-activated protein kinase 4-like carrying an MEY motif instead of a TXY motif is involved in ozone tolerance and regulation of stomatal closure in tobacco. J. Exp. Bot. 2016, 67, 3471-3479. [CrossRef] [PubMed]

53. Foyer, C.H.; Noctor, G. Oxygen processing in photosynthesis: Regulation and signalling. New Phytol. 2000, 146, 359-388. [CrossRef]

54. Ahammed, G.J.; Xu, W.; Liu, A.; Chen, S. COMT1 silencing aggravates heat stress-induced reduction in photosynthesis by decreasing chlorophyll content, photosystem II activity, and electron transport efficiency in tomato. Front. Plant Sci. 2018, 9, 998. [CrossRef] [PubMed]

55. Chen, Y.-E.; Liu, W.-J.; Su, Y.-Q.; Cui, J.-M.; Zhang, Z.-W.; Yuan, M.; Zhang, H.-Y.; Yuan, S. Different response of photosystem II to short and long-term drought stress in Arabidopsis thaliana. Physiol. Plant. 2016, 158, 225-235. [CrossRef] [PubMed] 
56. Ziaf, K.; Loukehaich, R.; Gong, P.; Liu, H.; Han, Q.; Wang, T.; Li, H.; Ye, Z. A multiple stress-responsive gene ERD15 from Solanum pennellii confers stress tolerance in tobacco. Plant Cell Physiol. 2011, 52, 1055-1067. [CrossRef] [PubMed]

57. Wu, F.Z.; Bao, W.K.; Li, F.L.; Wu, N. Effects of water stress and nitrogen supply on leaf gas exchange and fluorescence parameters of Sophora davidii seedlings. Photosynthetica 2008, 46, 40-48. [CrossRef]

58. Johnson, M.P.; Ruban, A.V. Arabidopsis plants lacking PsbS protein possess photoprotective energy dissipation. Plant J. 2010, 61, 283-289. [CrossRef]

59. Horton, P.; Johnson, M.P.; Perez-Bueno, M.L.; Kiss, A.Z.; Ruban, A.V. Photosynthetic acclimation: Does the dynamic structure and macro-organisation of photosystem II in higher plant grana membranes regulate light harvesting states? FEBS J. 2008, 275, 1069-1079. [CrossRef]

60. Ware, M.A.; Belgio, E.; Ruban, A.V. Comparison of the protective effectiveness of NPQ in Arabidopsis plants deficient in PsbS protein and zeaxanthin. J. Exp. Bot. 2015, 66, 1259-1270. [CrossRef]

61. Ort, D.R.; Baker, N.R. A photoprotective role for $\mathrm{O}_{2}$ as an alternative electron sink in photosynthesis? Curr. Opin. Plant Biol. 2002, 5, 193-198. [CrossRef]

62. Mahajan, S.; Tuteja, N. Cold, salinity and drought stresses: An overview. Arch. Biochem. Biophys. 2005, 444, 139-158. [CrossRef] [PubMed]

63. Ahammed, G.J.; Xu, W.; Liu, A.; Chen, S. Endogenous melatonin deficiency aggravates high temperature-induced oxidative stress in Solanum lycopersicum L. Environ. Exp. Bot. 2018. [CrossRef]

64. Rolny, N.; Costa, L.; Carrión, C.; José, J. Is the electrolyte leakage assay an unequivocal test of membrane deterioration during leaf senescence? Plant Physiol. Biochem. 2011, 49, 1220-1227. [CrossRef] [PubMed]

65. Gomathi, R.; Manohari, G.; Rakkiyappan, P. Antioxidant enzymes on cell membrane integrity of sugarcane varieties differing in flooding tolerance. Sugar Tech. 2012, 14, 261-265. [CrossRef]

66. Zaidi, I.; Ebel, C.; Belgaroui, N.; Ghorbel, M.; Amara, I.; Hanin, M. The wheat MAP kinase phosphatase 1 alleviates salt stress and increases antioxidant activities in Arabidopsis. J. Plant Physiol. 2016, 193, $12-21$. [CrossRef] [PubMed]

67. Miller, G.; Suzuki, N.; Rizhsky, L.; Hegie, A.; Koussevitzky, S.; Mittler, R. Double mutants deficient in cytosolic and thylakoid ascorbate peroxidase reveal a complex mode of interaction between reactive oxygen species, plant development, and response to abiotic stresses. Plant Physiol. 2007, 144, 1777-1785. [CrossRef] [PubMed]

68. Giraud, E.; Ho, L.H.M.; Clifton, R.; Carroll, A.; Estavillo, G.; Tan, Y.-F.; Howell, K.A.; Ivanova, A.; Pogson, B.J.; Millar, A.H.; et al. The absence of ALTERNATIVE OXIDASE1a in Arabidopsis results in acute sensitivity to combined light and drought stress. Plant Physiol. 2008, 147, 595-610. [CrossRef]

69. Nahar, K.; Hasanuzzaman, M.; Alam, M.M.; Rahman, A.; Suzuki, T.; Fujita, M. Polyamine and nitric oxide crosstalk: Antagonistic effects on cadmium toxicity in mung bean plants through upregulating the metal detoxification, antioxidant defense and methylglyoxal detoxification systems. Ecotoxicol. Environ. Saf. 2016, 126, 245-255. [CrossRef]

70. Ning, J.; Li, X.; Hicks, L.M.; Xiong, L. A Raf-Like MAPKKK gene DSM1 mediates drought resistance through reactive oxygen species scavenging in Rice. Plant Physiol. 2010, 152, 876-890. [CrossRef]

71. Apel, K.; Hirt, H. Reactive oxygen species: Metabolism, oxidative stress, and signal transduction. Annu. Rev. Plant Biol. 2004, 55, 373-399. [CrossRef] [PubMed]

72. Choudhury, S.; Panda, P.; Sahoo, L.; Panda, S.K. Reactive oxygen species signaling in plants under abiotic stress. Plant Signal. Behav. 2013, 8, e23681. [CrossRef] [PubMed]

73. Bavi, K.; Kholdebarin, B.; Moradshahi, A. Effect of cadmium on growth, protein content and peroxidase activity in pea plants. Pak. J. Bot. 2011, 43, 1467-1470.

74. Soudek, P.; Petrová, Š.; Vaňková, R.; Song, J.; Vaněk, T. Accumulation of heavy metals using Sorghum sp. Chemosphere 2014, 104, 15-24. [CrossRef] [PubMed]

75. Huang, X.; Luo, T.; Fu, X.; Fan, Q.; Liu, J. Cloning and molecular characterization of a mitogen-activated protein kinase gene from Poncirus trifoliata whose ectopic expression confers dehydration/drought tolerance in transgenic tobacco. J. Exp. Bot. 2011, 62, 5191-5206. [CrossRef]

76. Pan, J.; Zhang, M.; Kong, X.; Xing, X.; Liu, Y.; Zhou, Y.; Liu, Y.; Sun, L.; Li, D. ZmMPK17, a novel maize group D MAP kinase gene, is involved in multiple stress responses. Planta 2012, 235, 661-676. [CrossRef] [PubMed]

77. Ruelland, E.; Vaultier, M.N.; Curie, M.; Galile, R.; Seine, I. Cold signalling and cold acclimation in Plants. Adv. Bot. Res. 2009, 49, 35-150. [CrossRef] 
78. Van Den Ende, W.; Valluru, R. Sucrose, sucrosyl oligosaccharides, and oxidative stress: Scavenging and salvaging? J. Exp. Bot. 2009, 60, 9-18. [CrossRef]

79. Zhang, H.; Liu, W.; Wan, L.; Li, F.; Dai, L.; Li, D.; Zhang, Z.; Huang, R. Functional analyses of ethylene response factor JERF3 with the aim of improving tolerance to drought and osmotic stress in transgenic rice. Transgenic Res. 2010, 19, 809-818. [CrossRef]

80. López-Millán, A.F.; Sagardoy, R.; Solanas, M.; Abadía, A.; Abadía, J. Cadmium toxicity in tomato (Lycopersicon esculentum) plants grown in hydroponics. Environ. Exp. Bot. 2009, 65, 376-385. [CrossRef]

81. Ahammed, G.J.; Choudhary, S.P.; Chen, S.C.; Xia, X.J.; Shi, K.; Zhou, Y.H.; Yu, J. Role of brassinosteroids in alleviation of phenanthrene- cadmium co-contamination-induced photosynthetic inhibition and oxidative stress in tomato. J. Exp. Bot. 2013, 64, 199-213. [CrossRef] [PubMed]

82. Saitou, N.; Nei, M. The neighbor-joining method: A new method for reconstructing phylogenetic trees. Mol. Biol. Evol. 1987, 4, 406-425. [CrossRef] [PubMed]

83. Horsch, R.B.; Fry, J.E.; Hoffmann, N.L.; Eichholtz, D.; Rogers, S.G.; Fraley, R.T. A simple and general method for transferring genes into plants. Science 1985, 227, 1229-1231.

84. Livak, K.J.; Schmittgen, T.D. Analysis of relative gene expression data using real-time quantitative PCR and the $2^{\wedge}(-\Delta \Delta \mathrm{CT})$ method. Methods 2001, 25, 402-408. [CrossRef] [PubMed]

85. Ou, L.J.; Dai, X.Z.; Zhang, Z.Q.; Zou, X.X. Responses of pepper to waterlogging stress. Photosynthetica 2011, 49, 339-345. [CrossRef]

86. Shekhawat, U.K.S.; Srinivas, L.; Ganapathi, T.R. MusaDHN-1, a novel multiple stress-inducible SK3-type dehydrin gene, contributes affirmatively to drought- and salt-stress tolerance in banana. Planta 2011, 234, 915-932. [CrossRef] [PubMed]

87. Campos, P.S.; Quartin, V.; Ramalho, J.C.; Nunes, M.A. Electrolyte leakage and lipid degradation account for cold sensitivity in leaves of Coffea sp. plants. J. Plant Physiol. 2003, 160, 283-292. [CrossRef]

88. Arnon, D.I. Copper enzymes in isolated chloroplasts. Polyphenoloxidase in Beta vulgaris. Plant Physiol. 1949, 24, 1-15. [CrossRef]

89. Fukao, T.; Xu, K.; Ronald, P.C.; Bailey-Serres, J. A variable cluster of ethylene response factor-like genes regulates metabolic and developmental acclimation responses to submergence in rice. Plant Cell 2006, 18, 2021-2034. [CrossRef]

90. Zhang, G.; Chen, M.; Li, L.; Xu, Z.; Chen, X.; Guo, J.; Ma, Y. Overexpression of the soybean GmERF3 gene, an AP2/ERF type transcription factor for increased tolerances to salt, drought, and diseases in transgenic tobacco. J. Exp. Bot. 2009, 60, 3781-3796. [CrossRef]

91. Sergiev, I.; Alexieva, V.; Karanov, E. Effect of spermine, atrazine and combination between them on some endogenous protective systems and stress markers in plants. Proc. Bulg. Acad. Sci. 1997, 51, 121-124.

92. Thordal-Christensen, H.; Zhang, Z.; Wei, Y.; Collinge, D.B. Subcellular localization of $\mathrm{H}_{2} \mathrm{O}_{2}$ in plants. $\mathrm{H}_{2} \mathrm{O}_{2}$ accumulation in papillae and hypersensitive response during the barley-powdery mildew interaction. Plant J. 1997, 11, 1187-1194. [CrossRef]

93. Guo, W.L.; Chen, R.G.; Gong, Z.H.; Yin, Y.X.; Ahmed, S.S.; He, Y.M. Exogenous abscisic acid increases antioxidant enzymes and related gene expression in pepper (Capsicum annuum) leaves subjected to chilling stress. Genet. Mol. Res. 2012, 11, 4063-4080. [CrossRef] [PubMed]

94. Jiang, M.; Zhang, J. Effect of abscisic acid on active oxygen species, antioxidative defence system and oxidative damage in leaves of maize seedlings. Plant Cell Physiol. 2001, 42, 1265-1273. [CrossRef] [PubMed]

Sample Availability: Not Available. 